\title{
CAPITAL FOR SMALL BUSINESS: SOURCES AND METHODS
}

\author{
Bernard D. Cahn*
}

The recurrent debate during the past quarter century on the financial needs of the small business concern has led finally to the adoption of the Small Business Investment Act of $1958,{ }^{1}$ which establishes another potential source of loans and equity funds for some small business concerns. The Senate Committee on Banking and Currency, in its report, ${ }^{2}$ supported its recommendation of the statute by references to testimony and conclusions of witnesses and others that small business has unnecessarily great difficulty in obtaining term loans and equity capital. ${ }^{3}$

The Federal Reserve System, however, in its exhaustive study of the financing problems of small business, ${ }^{4}$ found it difficult to arrive at definitive answers to the questions involved. Its report contains papers setting forth conflicting views on whether the small businessman does, indeed, lack adequate sources of capital, ${ }^{5}$ and concludes: $:^{\mathrm{B}}$

As suggested earlier, perhaps it will never be possible to determine, on the basis of

- LL.B. 1933, University of Chicago. Member of the New York, Illinois, and Missouri bars; member of the National Council of Consultants of the United States Small Business Administration. Formerly, Assistant to the Director, Reorganization Division, and Special Advisor, Division of Corporation Finance, Securities and Exchange Commission.

${ }_{72}$ STAT. 689, I5 U.S.C.A. $\$ 633$ (Supp. I959).

${ }^{2}$ Senate Committee on Banking and Currency, Report, S. REP. No. 1652, 85th Cong., 2d Sess. (1958) [hereinafter cited as SeNATE REPORT].

${ }^{3}$ Documentation included U.S. Bureatu of Census, Dep't of Commerce, Survey of Reports of Credit and Capital Difficulties by SMaII Manufacturers (I935) (based on replies to questionnaires by 6,158 firms employing between 21 and 250 employees); Hearings before the Senate Select Committee on Small Business, 78th Cong., ist Sess. (1943); Resenrch and Policy Committee of the Committee on Economic Development, Meeting the Special Problems of Smali Business, A Statement on National PouIcy (1947); Hearings before the Senate Committee on Banking and Currency on the Small Business Act of 1950, 81st Cong., 2d Sess. (1950); McHugh and Ciaccio, External Financing of Small and MediumSize Business, Survey of Current Business, Oct. 1955, p. 15. Cf. Charles O. Hardy \& Jacob Viner, Report on the Avallability of Bank Credit in the Seventh Federal Reserve District (i935); Stoddard, Small Business Wants Capital, i 8 Harv. Bus. Rev. 265 (I940); Weissman, Raising Capital for Small Business, Challenge Magazine, Jan. I958, p. 8; Johnson, Scanlon, Friend, \& Shapiro, Shortage of Surplus of Funds to Finance Business, 12 J. Finswce 264 (1957); Murphy, Big Worry for Small Business, Fortune Magazine, July 1957 , p. I20, which arrive at the same general conclusions. But see Schweiger, Adequacy of Small Business Financing: Another View, in Federal Reserve Systex, 85th Cong., 2d Sess., Financing Small Business 124 (Comm. Print 1958) [hereinafter cited as Federal Reserve Report]. Loucheim, The Problem of Long Term and Equity Capital, II LAW \& ConTEMP. Prob. 248 (I945); Donham, Whither Small Business, 35 Harv. Bus. Rev. 73 (1957), which cast doubt on some of the conclusions in the Senate Report.

'Federal Reserve Report.

- Compare Kaplan \& Banner, Adequacy of Small-Business Financing: One View, in FEDERAL RESERve REPORT 107, with Schweiger, supra note 3. Only the former paper supported and was cited in the Senate Report. See SeNate Report 5.

- Federal Reserve Report I7-I8. 
statistical evidence alone, the nature and extent of existing imperfections and unfilled needs in the financing of small business. The notion of need itself is elusive and to a certain degree unverifiable. ... There is some evidence in the background studies, however, that there is an unfilled margin, perhaps a rather thin one, between the volume of funds available to small concerns in general, and to new firms in particular, and the volume that could be put to use without prohibitive risk. It is also possible that this margin varies with changes in credit and business conditions.

Perhaps the best help for small business at the present stage of economic development would be the maintenance of an expanding, reasonably stable economy, with personal incomes rising. This is not inconsistent with the desirability of broadening the financial facilities available to small business, but it suggests that the net contribution to small business to be expected from such facilities would be relatively minor compared with the more generalized effects of the maintenance of all-around business prosperity.

The position of the small businessman in our national structure poses not only economic problems, but political and sociological ones, as well; and the differences in conclusion may be traceable, in part, to the differences in function and purpose of the various participants in the debate. To the small businessman, however, faced with the practical problem of raising capital to improve his position, the national debate may be confusing. His thinking, which relates to a specific fact situation, may be unduly influenced by the broad conclusions of legislators, economists, and others, stated in terms of the national problem. Many businessmen have avoided the recognized capital markets because of lack of understanding of facilities available to them; others, previously unable to raise capital, may now have the mistaken impression that the new Act will permit them to accomplish more than the facts warrant.

Small business has had and will continue to have problems in the financial field, but external capital (i.e., capital not produced by the company's earnings and excluding ordinary trade and bank credit) is available on a competitive basis to a substantial number of growth companies in the small business category. As in other fields, the smaller enterprise must overcome its competitive disadvantage, resulting in part from size, by appropriate inducements.

\section{I}

\section{Size of THE Acceptable UNIT}

The size and acceptability of the unit must, for investment purposes, be measured in terms of several dimensions: management, size of assets, earnings and net worth, nature of industry and business, earnings trends and growth potential, market factors, nature of the capital desired, and others. A private investor may have one set of standards; an institutional lender, another $;^{7}$ and the public markets, a third. There is a close relationship among them, but each is independent. And the businessman must know all three in order to arrive at an informed decision on his specific problem.

At the lowest end of the scale are the businesses generally too small to interest an

"See, e.g., size categories established by Federal Reserve Banks, depending on the industry. FEDERAL RESERVE REPORT I6I. 
independent investor. Such units constitute eighty-two per cent or more of all the businesses in the country ${ }^{8}$ they are, in substance, no more than jobs for their owners. The corner retail store, the small stamping plant, the gas station, and other similar enterprises usually fall in that category. Almost all of such businesses are financed by personal resources and those of friends and relatives. Insurance policy loans are a significant source of funds to such small entrepreneurs. At the other end of the scale, for purposes of this analysis, is the small business approaching intermediate size, which has attributes sufficiently interesting to investors to be able to do public or institutional financing with little difficulty. In between the two extremes of the small business community are various indistinct dividing points separating the units acceptable for investment of external capital from those that are not able to raise external capital from private investors, institutions, or public investors.

Surveys of available data with respect to public and private investment support the following conclusions:

r. It is difficult, if not impossible, to generalize on the size and nature of a business that can attract funds from individual or venture-capital sources. Venture-capital investors usually seek large capital gains. Such gains are not dependent on size, but on the nature of the business.

2. Surveys of leading life insurance companies indicate that institutional loans are available in amounts as low, at times, as $\$ 100,000$ or less. Borrowers with net worths above the $\$ 250,000-350$,000 level (usually with total assets exceeding $\$ 1,000,000$ ), meeting certain standards of soundness and growth potential, receive serious consideration for institutional loans. The determination of a good risk, however, will depend on more than net worth or asset size.

3. Equal difficulty is experienced in attempting to describe the company sufficiently large to raise funds via the public offering route. Here, again, growth potential, earnings record, calibre of management, nature of the business, and many other factors affect the ability of a company to enter the financial markets. The timing of the offering is also of some importance. Generally speaking, however, a company with minimum net earnings after taxes of $\$ 100,000$ to $\$ 150,000$, a net worth of $\$ 400,000$ to $\$ 500,000$, a record of growth and further growth potential, in an attractive field, and with acceptable management would be able to make a public offering of securities. Total assets and sales are usually only minor measurement standards.

II

Problems Affecting Financing of the Small Business

A. Competition for Funds

The economic history of the United States has been marked by increasing amounts of capital invested per worker employed, with increasing productivity per worker and

${ }^{8}$ See Roy A. Foulke, Practical Financial Statement Analysis I5I (4th ed. 1957). 
a rising standard of living. The amount spent on producers' durable equipment has quintupled in twenty-five years. Although other factors have contributed to stimulate this increase, high wage costs and competition are the principal spurs to more plant investment. The competition for savings has been increasingly keen in recent years, and present prospect is for continued high money rates and tight money markets. In a dynamic growing economy, the needs of entrepreneurs may exceed available capital resources. ${ }^{10}$ At best, there will be an unsatisfied demand, with all businesses-small, medium, and large-competing for the investors' funds. Increasing concentration of savings in the hands of institutions, investment trusts, and other similar investors means that small business, more and more, must meet recognized competitive standards of performance, management, and growth potential in order to raise new capital.

\section{B. Approach to the Market}

The popular literature on the financial woes of the small businessmen is replete with stories of the frustration and disaster which await the small businessman who ventures alone into the capital market. ${ }^{11}$ Undoubtedly, some of the frightening examples result from lack of experience. The financial market is a complex mechanism which includes many different kinds of financial houses, institutions, private investors, and other sources of capital and term loan funds. Each has its own role to play, and that role must be understood. Contact with the right source of funds requires study of the company's needs, as well as knowledge of the ramifications of the market place.

\section{Capital Structure}

At best, the design of a proper capital structure is a difficult, complex task. Various kinds of debt and equity securities are available for the company's purposes: secured, unsecured, and subordinate bonds and debentures, convertible and nonconvertible, refundable and nonrefundable, with and without sinking funds, and with a variety of terms and conditions. Different classes of stock, with a host of special provisions to choose from, may be designed to meet the issuer's financial problems. ${ }^{12}$ Fashions and fads in securities must be taken into account. ${ }^{13}$ Institutions and underwriters (and sometimes knowledgeable private investors) will insist upon the observance of certain standards of interest coverage, and ratios of debt to net worth and working capital. No general formulae are available; each case requires a tailor-made structure.

- Cf. Financing Your Company, address by Andrew Overby, Vice President, First Boston Corporation, and former Assistant Secretary of the Treasury, before the Third Annual Industrial Economics Conference, Los Angeles, Cal., reported in Commercial and Financial Chronicle, Jan. 23, 1958, p. I.

${ }^{10}$ Sce Federal Reserve Report I9.

${ }^{11}$ Cf. Murphy, supra note 3 . The constant reference to the difficulties of the small businessman in meeting financial problems has apparently had an effect on the thinking of businessmen who require financing. Surveys indicate that many who require financing do not seek it because they believe they will not be able to obtain it. See Federal Reserve Report i7.

${ }^{10}$ Cf. Mendel, Recent Financing Patterns and Their Derivation, Bus. Law, July 1956, p. Ix7; Louis

O. Foster, Corporate Debt and the Stockholder (1956).

${ }^{13}$ See 2 Arthur S. Dewing, Financial Policy of Corporations 1029 (5th ed. 1953). 
The design of a proper capital structure frequently is complicated because of prejudices and misunderstandings of the small businessman. Almost without exception, capital sources report that the small businessman insists upon raising capital in the form of term loans, whereas his business usually requires equity funds. ${ }^{14}$ The objections of the businessman often are related to (I) fear of loss of control (with consequent restrictions on emoluments as well as freedom of decision), and (2) reluctance to dilute earnings. Such objections may be based on misconceptions. The institutional lender and the reputable public offering underwriters are interested in the continuance of competent management and control. They seek to perpetuate it rather than to undermine it. Furthermore, a sufficient distribution of securities to the public permits control by management with substantially less than fifty-one per cent ownership. Finally, control positions can be preserved in a number of ways which will assure even the most apprehensive that he will not be unseated.

The objection based on earnings dilution may also be ill-founded. If the new capital is well used, it should return a fair profit per share, so that the profit position of the owner is not diluted, but is enhanced. ${ }^{\mathbf{1 5}}$ The difference in interest income available to the investor in connection with an investment in a small business usually does not compensate him adequately for the risk involved. He looks to the small company primarily for growth potential and capital gain. The small businessman who would expand must determine to part with some equity if he is to do the type of financing necessary for his own growth and to prevent stagnation or even deterioration. ${ }^{16} \mathrm{He}$ must recognize that usually a smaller share in a larger enterprise may be more beneficial than complete ownership of a company impeded by lack of adequate financing.

\section{Earnings and Growth Potential}

Among knowledgeable investors, there is the impression that small businesses, as a group, are more volatile in earnings from year to year, and not more profitable per dollar of investment, than larger, well-established enterprises. The earnings data in table one indicate that for most of the past two years, earnings of the smaller businesses have been below average. ${ }^{17}$

The data do indicate greater volatility in the smaller categories. But no clear conclusions emerge in comparing profitability per dollar of investment. The above data are, in fact, averages whereas the growth company is an above-average prospect, almost by definition. Also, the accounting practices of the small businessman may not be as accurate as those of his larger competitors. Furthermore, salaries of the

\footnotetext{
16 In the insurance survey described below, many of the replying insurance companies stated that the insistence of undercapitalized borrowers on loans instead of equity capital funds constituted, in many cases, an obstacle to an effective financing program. Cf. Frederal Reserve Report I3; Donham, supra note 3 .

${ }^{16}$ See Weaver, Equity Financing for the Small Firm, 34 HARv. Bus. Rev. 9 I (1956).

${ }^{10}$ Some executives point out that failure to grow and keep pace with competition may lead to ultimate failure. Cf. Katona, How Business Meets Money Needs, Nation's Business, Dec. 1957, p. 32.

${ }^{17}$ Based on the Quarterly Financial Reports published by the FTC and the SEC.
} 
TABLE I

Annual Rates of Profit on Stockholders' Equity by Asset Size (per cent)

\begin{tabular}{|c|c|c|c|c|c|c|c|c|c|c|c|}
\hline \multirow[b]{2}{*}{ Asset Size } & \multicolumn{11}{|c|}{ Before FEDERAL INCOAF Taxes } \\
\hline & $\begin{array}{c}Q 1 \\
1956\end{array}$ & $\begin{array}{c}\mathrm{Q} 2 \\
1956\end{array}$ & $\begin{array}{c}Q 3 \\
1956\end{array}$ & $\begin{array}{c}Q 4 \\
1956\end{array}$ & $\begin{array}{c}Q 1 \\
1957\end{array}$ & $\begin{array}{c}\mathrm{Q} 2 \\
1957\end{array}$ & $\begin{array}{c}Q 3 \\
1957\end{array}$ & $\begin{array}{c}Q 4 \\
1957\end{array}$ & $\begin{array}{c}Q 1 \\
1958\end{array}$ & $\begin{array}{c}Q 2 \\
1058\end{array}$ & $\begin{array}{c}\mathrm{Q3} \\
1058\end{array}$ \\
\hline II asset sizes & 23.8 & 24.2 & 20.2 & 22.3 & 22.5 & 21.6 & 19.1 & 16.8 & 12.9 & 13.9 & 15.9 \\
\hline $\begin{array}{l}\text { Under } \$ 250,000 \ldots \ldots \ldots \ldots \\
\$ 250,000 \text { to } \$ 999,999 . \ldots \ldots \\
\$ 1,000,000 \text { to } \$ 4,999,999 . \ldots \\
\$ 5,000,000 \text { to } \$ 9,999,999 . \ldots \\
\$ 10,000,000 \text { to } \$ 49,999,999 . .\end{array}$ & $\begin{array}{l}17.3 \\
18.9 \\
21.4 \\
22.2 \\
22.6\end{array}$ & $\begin{array}{l}24.0 \\
22.1 \\
21.5 \\
22.5 \\
24.5\end{array}$ & $\begin{array}{l}25.2 \\
23.0 \\
21.4 \\
21.3 \\
22.5\end{array}$ & $\begin{array}{l}13.0 \\
12.8 \\
18.9 \\
19.5 \\
23.3\end{array}$ & $\begin{array}{l}15.6 \\
15.7 \\
18.8 \\
18.0 \\
21.1\end{array}$ & $\begin{array}{l}19.4 \\
19.2 \\
19.7 \\
21.0 \\
21.4\end{array}$ & $\begin{array}{l}18.2 \\
20.4 \\
18.7 \\
19.7 \\
19.7\end{array}$ & $\begin{array}{r}5.5 \\
7.4 \\
12.2 \\
14.8 \\
16.8\end{array}$ & \begin{tabular}{r|}
1.5 \\
7.6 \\
8.9 \\
11.9 \\
12.4
\end{tabular} & $\begin{array}{r}9.2 \\
12.4 \\
13.0 \\
13.9 \\
14.1\end{array}$ & $\begin{array}{l}16.7 \\
16.3 \\
16.8 \\
17.8 \\
16.2\end{array}$ \\
\hline $\begin{array}{l}\$ 50,000,000 \text { to } \$ 99,999,999 . \\
\$ 100,000,000 \text { to } \$ 249,999,999 \\
\$ 250,000,000 \text { to } \$ 999,999,999 \\
\$ 1,000,000,000 \text { and over..... }\end{array}$ & $\left|\begin{array}{l}23.4 \\
24.1 \\
25.4 \\
25.9\end{array}\right|$ & $\begin{array}{l}24.2 \\
24.5 \\
25.7 \\
24.4\end{array}$ & $\begin{array}{l}23.0 \\
19.9 \\
20.3 \\
16.6\end{array}$ & $\begin{array}{l}22.5 \\
24.1 \\
23.9 \\
24.0\end{array}$ & $\begin{array}{l}22.0 \\
22.6 \\
22.1 \\
27.3\end{array}$ & $\begin{array}{l}21.4 \\
22.0 \\
21.2 \\
23.1\end{array}$ & $\begin{array}{l}20.7 \\
20.1 \\
19.4 \\
17.7\end{array}$ & $\begin{array}{l}17.5 \\
19.1 \\
17.7 \\
19.3\end{array}$ & $\begin{array}{l}14.3 \\
15.0 \\
13.9 \\
14.3\end{array}$ & $\begin{array}{l}14.9 \\
16.7 \\
15.3 \\
12.3\end{array}$ & $\begin{array}{l}17.9 \\
18.0 \\
17.8 \\
12.3\end{array}$ \\
\hline \multirow[b]{2}{*}{ Asset Size } & \multicolumn{11}{|c|}{ AFTER FEDERAL INCOME TAXES } \\
\hline & $\begin{array}{c}Q 1 \\
1956\end{array}$ & $\begin{array}{c}\mathrm{Q} 2 \\
1956\end{array}$ & $\begin{array}{c}Q 3 \\
1956\end{array}$ & $\begin{array}{c}Q 4 \\
1956\end{array}$ & $\begin{array}{c}Q 1 \\
1957\end{array}$ & $\begin{array}{c}Q 2 \\
1957\end{array}$ & $\begin{array}{c}Q 3 \\
1957\end{array}$ & $\begin{array}{c}84 \\
1957\end{array}$ & $\begin{array}{c}Q 1 \\
1958\end{array}$ & $\begin{array}{c}\mathbf{2 2} \\
1058\end{array}$ & $\begin{array}{c}Q 3 \\
1058\end{array}$ \\
\hline I a & 12.5 & 13.0 & 11.0 & 12.6 & 11.9 & 11.6 & 10.5 & 9.8 & 6.8 & 7.8 & 0.0 \\
\hline $\begin{array}{l}\text { Under } \$ 250 \\
\$ 250,000 \text { to } \\
\$ 1,000,000 \mathrm{t} \\
\$ 5,000,000 \mathrm{t} \\
\$ 10,000,000\end{array}$ & $\begin{array}{r}10.3 \\
9.5 \\
10.6 \\
10.7 \\
11.1\end{array}$ & $\begin{array}{l}15.6 \\
11.5 \\
10.4 \\
10.9 \\
12.2\end{array}$ & $\begin{array}{l}15.3 \\
11.7 \\
10.7 \\
10.4 \\
11.1\end{array}$ & $\begin{array}{r}5.8 \\
5.8 \\
9.1 \\
9.8 \\
11.8\end{array}$ & $\begin{array}{r}8.4 \\
7.5 \\
8.9 \\
8.4 \\
10.2\end{array}$ & $\begin{array}{r}11.1 \\
10.0 \\
9.6 \\
10.1 \\
10.5\end{array}$ & $\begin{array}{r}11.0 \\
10.1 \\
9.1 \\
9.7 \\
9.8\end{array}$ & $\begin{array}{l}0.7 \\
2.4 \\
5.4 \\
7.3 \\
8.7\end{array}$ & $\begin{array}{r}-3.0 \\
2.1 \\
2.9 \\
4.9 \\
5.8\end{array}$ & $\begin{array}{l}4.7 \\
5.7 \\
5.9 \\
6.4 \\
7.0\end{array}$ & $\begin{array}{r}10.3 \\
8.9 \\
8.0 \\
8.8 \\
8.0\end{array}$ \\
\hline $\begin{array}{l}\$ 50,000,000 \text { to } \$ 99,999,999 . . \\
\$ 100,000,000 \text { to } \$ 249,999,999 \\
\$ 250,000,000 \text { to } \$ 999,999,999 \\
\$ 1,000,000,000 \text { and over..... }\end{array}$ & $\begin{array}{l}11.8 \\
11.5 \\
13.2 \\
14.9\end{array}$ & $\begin{array}{l}12.3 \\
12.1 \\
13.6 \\
14.9\end{array}$ & $\begin{array}{r}11.6 \\
9.9 \\
10.9 \\
11.1\end{array}$ & $\begin{array}{l}11.8 \\
13.0 \\
13.6 \\
15.9\end{array}$ & $\begin{array}{l}11.1 \\
11.2 \\
11.8 \\
16.0\end{array}$ & $\begin{array}{l}11.1 \\
11.0 \\
11.3 \\
14.0\end{array}$ & $\begin{array}{l}10.4 \\
10.0 \\
10.3 \\
11.8\end{array}$ & $\begin{array}{r}9.2 \\
10.1 \\
10.3 \\
13.7\end{array}$ & $\begin{array}{l}7.3 \\
7.4 \\
7.4 \\
9.5\end{array}$ & \begin{tabular}{|l}
7.6 \\
8.5 \\
8.3 \\
8.8
\end{tabular} & $\begin{array}{l}0.2 \\
9.2 \\
0.6 \\
0.1\end{array}$ \\
\hline
\end{tabular}

owners and expense allowances may be larger in proportion to total earnings than they would be in the case of larger businesses. Nevertheless, the investor's unfavorable general impression of small business earnings ratios and fluctuations will have a bearing on the price and terms of the successful offering and on the unit selected for financing.

\section{E. Problems of Presentation}

Investment sources complain of the inability of the small businessman to make an adequate presentation of his business so that they may determine easily whether it is the type of enterprise in which they will be interested. The costs of examining businesses are quite high. Based on past experience, most institutional investors, venture-capital concerns, and underwriting firms know that only a small percentage of applicants will interest them. ${ }^{18}$ Accordingly, the preparation of the descriptive brochure, as well as presentation to the right source of funds, are matters of importance. A survey of the business, adequate financial analysis (including earnings

${ }^{18}$ See Federal Reserve Report 53 I. 
projections), data with respect to the markets and competition, detailed statements of financial needs and relation thereof to earnings, and growth statistics and other support for the asserted growth potential must be carefully developed if the application is to succeed.

\section{F. Problems of Management}

The average small businessman is experienced primarily in production, or sales, or both, and usually is not well grounded in internal finance. Many institutional investors and underwriting firms will refuse to finance a company that does not have an experienced treasurer or financial advisor. Good accounting and cost controls, and the ability of the accounting department to develop adequate data for management decisions are deemed important.

Of greater importance, perhaps, than any of the other complaints is that which is voiced against the strength of the management of the small enterprise. $^{10}$ As a normal matter, the investor wants only a passive role. He is unable, and it is too costly for him, to devote time to the daily administration of the company in which he has invested. Accordingly, there must be competent management in depth. In many cases, management is a one-man affair, and that one man is spread very thin. He is often a jack-of-all-trades and can attend only to the most urgent problems. The ability of a business to grow can often be measured in terms of its management depth and calibre.

In addition to the matter of depth to handle the daily operations, there is the problem of succession. A company which is dependent on one man may turn from a profitable to a failing operation upon the death or incapacity of that man. Replacements may not be available when the crisis arises. The refusal of management to fortify itself with younger men is often an effective barrier against financing.

Various solutions to these problems may be available. Merger with similar smaller companies, addition of developed products, expansion of personnel, engagement of engineers, market specialists, and other professional experts, and similar methods may assist in developing a successful financial program.

\section{III}

\section{Sources of Funds: Private Investors 20}

In some instances, private capital may be the only kind available to the small enterprise. In other cases, where there is a choice, private capital may be preferable to fortify management, to provide banking facilities, or for cost reasons. Usually, however, the smaller initial costs of obtaining private venture capital (savings of pro-

${ }^{10} \mathrm{Cf}$. id. at 322 .

20 This section is based primarily on experiences of this writer and, in part, on a recent limited survey of the field contained in the Federal Reserve Report. The latter reflects interviews with II private investors and II venture-capital funds (plus a few brokers and others). Of these, only 7 were based in New York. The survey is admittedly too limited for statistical purposes, and some of the answers given by the persons interviewed (as to control, for example) may be open to serious question. However, the consensus of opinion on some problems, particularly size, appears to be sound. 
fessional fees, printing costs, and the like) will be compensated for in the basic cost of the private funds.

The sources of private capital include wealthy individuals, investing syndicates or groups (including investment banking firms for the accounts of their partners or a few selected clients), closed-end investment companies, corporations seeking diversification, and venture-capital firms.

\section{A. New Enterprises}

The unusual idea or invention may, at times, attract venture capital (either in equity or loan form) at inception of the enterprise, if the promised reward appears great enough and its realization reasonable of anticipation. Businesses with dramatic electronic and military inventions, or in the fields of shipping, mineral exploitation, manufacture of aircraft rockets and related items, automobile-parking devices, unusual industrial items, and many others have been financed before the success of the device was proved. Each case is a separate problem, and few generalizations, if any, can be drawn from a cross section. The inventor or owner with no funds may find it necessary to part with control in exchange for living expenses and funds for development. Usually, a prototype of the invention must be developed to lure the capital, and the inventor who requires funds to build the prototype is, indeed, in a difficult position (although, on occasion, even that kind of financing can be found).

During the past decade or more, at times when the country's speculative fervor has been great, many new enterprises have been financed by small public offerings, often on a basis substantially more favorable to the owner than would have been accorded to him by knowledgeable private investors. ${ }^{21}$ However, the resultant high incidence of failure, not fully appreciated initially by the public investor, has effectively reduced the number of prospective investors in this type of speculation as each cycle has run its course. Only under unusual circumstances will the established financial firm today lend its name to such public offerings of new enterprises.

\section{B. Established Enterprises}

Private capital is more readily available for the enterprise with some record of earnings. The earnings potential must be substantial, and many sources require the company to be of sufficient size to merit an investment in excess of $\$ 100,000$ (some sources require a minimum of $\$ 250,000$ ), because of the expense of investigation and other factors. ${ }^{22}$ The private investor will often insist upon a position which will

${ }^{21}$ Such offerings are usually made under SEC Reg. A, and offerings of this type, often of securities not suitable for the public investor, have brought Reg. A into some disrepute. There has been some confusion between the problem of the small Reg. A offering and the financial problems of the small business community generally. Cf. Federal Reserve RePORT 539. Some persons have contended (because of speculative excesses) that small business offerings are all of doubtful validity. Others have concluded that the way to solve the financial problems of small business is to "liberalize" Reg. A (in substance, eliminating substantial requirements as to disclosure). Neither conclusion is sound.

${ }^{20} \mathrm{~A}$ partner in the J. H. Whitney \& Co., a leading venture-capital concern, stated in a specch before a session of the American Management Association on December 2, 1958, in New York that in the past I2 years, his concern had considered 7,000 enterprises or projects, but had made investments in only 50 of them. 
enable him to move quickly to protect his investment. This may require a shift of control under specified adverse conditions.

On occasion, private financing is supplied by investment firms or partners of investment firms who see prospect of an eventual successful public offering at a higher price and are willing to invest funds for a period until the company can be developed to public offering status. In such cases, the company or the principal stockholder will be able to sell less than a majority interest. At times, however, such deals, which have started with the sale of minority interests, have involved the sale of majority control before the public offering stage was reached. The investor must hold himself ready to provide all financing necessary to bring the company to the public offering stage. The increase in investment is not always voluntary.

As a general matter, private investment in the small business is viewed by the investor as a prelude to a public offering and resulting liquidity. The initial investment, however, is "frozen," since no market then exists. The period of "freeze" to which the venture-capital firm or investing group will submit varies from case to case, but it may run from two to five years. Some of the venture-capital funds establish as a goal a twenty per cent capital gain per year of investment, ${ }^{23}$ but that goal is not often reached.

In order to provide the investor with a capital gain opportunity, he must usually receive stock, or stock options, or both. On occasion, he may accept notes or bonds for the face amount of his investment, together with a substantial block of stock, options, or warrants for his potential capital gain. As is true with respect to other sources of capital funds for the small business, debt securities alone usually will not attract funds from private investors.

The small enterprise may sometimes be able to solve its problems by merger with a larger, well-established organization interested in diversification or in supplementary facilities or products. Such larger companies may pay more for an acquisition than any other source. Continuance of existing management can usually be assured by agreement, but control of the enterprise often passes to the acquiring corporation.

\section{IV}

\section{SOURCES OF Funds: INSTITUTIONAL LENDERs ${ }^{24}$}

One of the important financial developments in the past twenty years has been the growth of life insurance companies as the principal buyers of corporate debt

a Cf. Federal Reserve Report 536.

${ }^{26}$ The data in this section are based primarily on information collected by the writer in a survey of insurance companies conducted in September and October of 1958. The principal source of industrial loans to small business has been the life insurance companies, many of which are looking to the field for the first time. Hence, only life insurance companies were surveyed. Inquiries were directed to 80 companies (constituting substantially all) with admitted assets in excess of $\$ 100,000,000$ and about 20 with assets less than that amount. Replies were received from $75 \%$ of the insurance companies. Inquiries were supplemented by several personal interviews. In addition, reference has been made to Life Insurance Association of America, Survey of Life Insurance Loans to Business and Industry (Joint Investment Bull. No. 321, 1957) [hereinafter referred to as LIAA STudy], covering 67 companies 
securities. Private placements (nonpublic offerings) of corporate debt have risen from $\$ 1,004,000,000$ in 1945 , constituting 20.7 per cent of all corporate debt issues, to $\$ 3,389,000,000$ in 1956 , constituting 38.6 per cent of all corporate debt issues sold in that year. In 1957, insurance company purchases accounted for ninety per cent of total private corporate debt placements, and for the period from $x 953-56$, the insurance companies acquired about five-sixths of all such private debt placements. ${ }^{25}$

\section{A. Size of Borrower and Loan}

Although there are practical minimum size standards, the primary inquiry of the insurance lender relates to growth potential, stability, management, and competitive and market factors. A good risk may be below any rule-of-thumb minimum.

Of the country's eighty insurance companies with assets exceeding $\$ 100,000,000$, almost half have indicated that they have a policy of making industrial (nonreal estate) loans to businesses that may properly be considered in the small business category. ${ }^{26}$ The minimum sizes of loans and borrowers depend, in part, on the location of the borrowing company in relation to the lender; in part, on the facilities which the lender has established to sift applications and examine prospective borrowers; and in part, on the strength of management and other factors peculiar to each borrower. Money market conditions are also important.

Several of the insurance companies indicate that they will make industrial loans as low as $\$ 100,000$ (and in a few instances, below $\$ 100,000$ ). The others interested in loans to small business have indicated that they will lend in amounts of $\$ 250,000$ and more; a few have minimum loan limits of $\$ 500,000$.

The minimum size of the borrower is not determinable with any certainty, but borrowers with less than $\$ 250,000$ to $\$ 350,000$ of net worth find it very difficult to borrow from insurance companies. Most companies appear to prefer borrowers with total assets in excess of $\$ 1,000,000$ and posttax annual earnings at or above the $\$ 100,000$ level.

The foregoing reports of lending policies in 1958 may be compared with the analysis of life insurance company industrial loans in $1953-56$ in table two. ${ }^{27}$

A comparison of industrial size statistics with the above loan analysis indicates that only the upper part of the small business community has been receiving industrial loans in a proportion commensurate with its asset position. The business community has been analyzed from the asset viewpoint in table three (based on 1953 $\operatorname{tax}$ returns). ${ }^{28}$

with $77 \%$, of total life insurance assets. Such data were supplemented by reference to 2 DewiNo, op. cit. supra note I3, at I107-2I; E. R. Corey, Direct Placement of Corporate Securities (I95I); Federal Reserve Report 512-24; and 24 SEC ANN. REP. (1958). Note and loan agreements and other forms from the files of the writer and of other law firms and financial institutions were inspected and analyzed.

${ }^{25}$ LIAA STUdY; 24 SEC ANv. REP. (1958); SEC Statistical Bulletins.

${ }^{28}$ Companies below $\$ 100,000,000$ indicated no interest in industrial nonreal estate loans.

${ }^{27}$ LIAA STUDY tables $A-2$ and A-4.

${ }^{28}$ Federal Reserve Report i68-69. 
TABLE II

INSURANCE COMPANY LOANS

\begin{tabular}{|c|c|c|c|c|c|c|}
\hline \multirow[b]{2}{*}{$\begin{array}{c}\text { Asset Size of Obligor } \\
\text { (Millions) }\end{array}$} & \multicolumn{3}{|c|}{1953} & \multicolumn{3}{|c|}{1954} \\
\hline & $\underset{\text { Loans }}{\text { Amount of }}$ & $\begin{array}{c}\text { Average } \\
\text { Size of } \\
\text { Loan }\end{array}$ & $\begin{array}{l}\text { Per cent } \\
\text { of Total }\end{array}$ & $\underset{\text { Loans }}{\text { Amount of }}$ & $\begin{array}{l}\text { Average } \\
\text { Size of } \\
\text { Loan }\end{array}$ & $\begin{array}{l}\text { Per cent } \\
\text { of Total }\end{array}$ \\
\hline 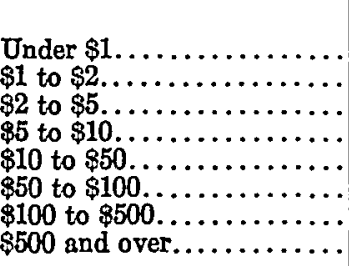 & \begin{tabular}{r|}
\multicolumn{2}{c}{ (Thous } \\
$\$ 6,517$ \\
30,739 \\
85,717 \\
146,447 \\
440,516 \\
304,874 \\
777,916 \\
983,760
\end{tabular} & $\begin{array}{l}\text { (nds) } \\
\$ \quad 163 \\
530 \\
779 \\
1,285 \\
1,907 \\
2,849 \\
2,749 \\
6,306\end{array}$ & $\begin{array}{r}.2 \\
1.1 \\
3.1 \\
5.3 \\
15.9 \\
11.0 \\
28.0 \\
35.4\end{array}$ & $\begin{array}{r}\text { (Thou } \\
7,365 \\
21,459 \\
88,037 \\
143,171 \\
661,699 \\
249,446 \\
713,136 \\
740,162\end{array}$ & $\begin{array}{r}\text { nds) } \\
\$ \quad 153 \\
523 \\
616 \\
967 \\
2,290 \\
2,835 \\
3,984 \\
6,220\end{array}$ & $\begin{array}{r}.3 \\
.8 \\
3.4 \\
5.4 \\
25.2 \\
9.5 \\
27.2 \\
28.2\end{array}$ \\
\hline \multirow[b]{2}{*}{$\begin{array}{c}\text { Asset Size of Obligor } \\
\text { (Millions) }\end{array}$} & \multicolumn{3}{|c|}{1955} & \multicolumn{3}{|c|}{1956} \\
\hline & $\begin{array}{l}\text { Amount of } \\
\text { Loans }\end{array}$ & $\begin{array}{c}\text { Average } \\
\text { Size of } \\
\text { Loan }\end{array}$ & $\begin{array}{l}\text { Per cent } \\
\text { of Total }\end{array}$ & $\begin{array}{c}\text { Amount of } \\
\text { Loans }\end{array}$ & $\begin{array}{l}\text { Average } \\
\text { Size of } \\
\text { Loan }\end{array}$ & $\begin{array}{l}\text { Per cent } \\
\text { of Total }\end{array}$ \\
\hline 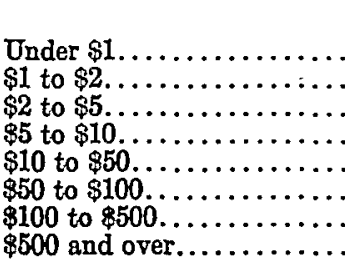 & $\begin{array}{r}\text { (Thous } \\
5,746 \\
22,954 \\
109,623 \\
151,271 \\
650,408 \\
324,120 \\
1,098,145 \\
316,450\end{array}$ & $\begin{array}{l}\text { ands) } \\
\$ \quad 185 \\
383 \\
850 \\
1,201 \\
1,891 \\
1,884 \\
4,673 \\
2,416\end{array}$ & $\begin{array}{r}.2 \\
.9 \\
4.1 \\
5.6 \\
24.3 \\
12.1 \\
41.0 \\
11.8\end{array}$ & $\begin{array}{r}\text { (Thou } \\
6,509 \\
23,133 \\
133,702 \\
184,965 \\
687,732 \\
569,749 \\
1,128,725 \\
656,451\end{array}$ & $\begin{array}{r}\text { (nds) } \\
\$ \quad 224 \\
454 \\
955 \\
1,321 \\
1,926 \\
3,063 \\
3,300 \\
3,907\end{array}$ & $\begin{array}{r}.2 \\
.7 \\
3.9 \\
5.4 \\
20.3 \\
16.8 \\
33.3 \\
19.4\end{array}$ \\
\hline
\end{tabular}

Slightly more than ten per cent of all industrial loans by life insurance companies during the $1953-5^{6}$ period were to companies with assets under $\$ 10,000,000$. Based on the above statistical sample, it may be concluded that companies in that size category held 34.I per cent of total corporate assets during I953. A similar comparison of loans and assets with respect to companies with assets between $\$ \pi, 000,000$. and $\$ 5,000,000$ indicates a closer correlation. Companies of that size owned about 9.8 per cent of total corporate assets and received about 4.5 per cent of the nonmortgage loans by life insurance companies during the period. In the area of $\$ 5,000,000-\$ 10,000,000$ of assets, the correlation between asset position and total loans is remarkably close. Companies of that size accounted for 5.5 per cent of total assets and received 5.4 per cent of total loans.

In addition, the insurance companies loaned over $\$ 4,250,000,000$ to business and industry on mortgage loans in the period 1953-56. An analysis of all such loans in terms of size of borrower is not available, but an analysis of about one-third of the loans indicated that approximately sixty per cent were made to borrowers with less than $\$ 5,000,000$ of assets. ${ }^{29}$

The complaint of lack of loan funds comes principally from the multitude of

${ }^{20}$ LIAA STUDY table C-2. 
TABLE III

Asset Position

\begin{tabular}{c|c|c}
\hline Total Assets & $\begin{array}{c}\text { Asset Size } \\
\text { (Per cent of total) }\end{array}$ & $\begin{array}{c}\text { Number } \\
\text { (Per cent of total) }\end{array}$ \\
\cline { 2 - 3 } Under $\$ 50,000 \ldots \ldots \ldots \ldots \ldots \ldots$ & 5.7 & 92.2 \\
$\$ 50,000-\$ 100,000 \ldots \ldots \ldots \ldots \ldots$ & 2.8 & 3.5 \\
$\$ 100,000-\$ 250,000 \ldots \ldots \ldots \ldots$ & 4.0 & 2.4 \\
$\$ 250,000-\$ 1,000,000 \ldots \ldots \ldots \ldots$ & 6.4 & 0.3 \\
$\$ 1,000,000-\$ 5,000,000 \ldots \ldots \ldots$ & 9.8 & 0.4 \\
Above $\$ 10,000,000 \ldots \ldots \ldots \ldots \ldots$ & 5.5 & 0.1 \\
\hline
\end{tabular}

prospective borrowers at the lowest end of the business scale. The insurance companies contend that such borrowers are not able to meet the standards which they must observe. Many applicants with less than $\$ 1,000,000$ in total assets, and almost all those in the area under $\$ 250,000$ of total assets, are said to lack the characteristics of a sound borrower not because of size alone (although size in the lower levels is increasingly important), but because of their inability to meet standards with respect to earnings, stability, management, and the like which the lenders are required to observe. Furthermore, loans to companies at the lowest end of the scale usually are not profitable to the lender. The difference between the maximum interest which the insurance company will charge and the interest rate of higher-grade loans is not sufficient either to measure the risk ${ }^{30}$ or to compensate for increased costs.

\section{B. Other Limitations and Considerations}

No general pattern of area or type restrictions is discernible in the analysis of loan policies. Some companies will lend on a nation-wide basis, except that an isolated loan in an area where the company has no other business must be of sufficient size to justify the expense of examination and supervision. Others restrict themselves to the area adjacent to the lender's home office or to the area where the lender's insurance business is conducted. A few companies exclude loans to certain industries.

Where the applicant is attempting to remedy undercapitalization by overborrowing, a limited public offering may supply the capital necessary to satisfy the insurance companies, and the fact that the insurance company is willing to make a loan to such a company may facilitate the public offering.

Many of the insurance lenders are interested in inflation hedges such as options, warrants, conversion features, and the like. Such considerations, at times, may induce the making of a loan which is not competitive solely on an interest basis. On occasion, preferred stock will be purchased.

Generally speaking, loans exceeding one-third to one-half the amount of the borrower's net worth are frowned upon. Interest coverage (ratio of operating earnings to total interest requirements) of at least four times (some companies indicate

${ }^{80}$ Most recognized leaders, particularly in the institutional field, will not permit a rate substantially in excess of $6 \%$. Cf. Federal Reserve Report I5. 
much higher) may be insisted upon. Most companies require a ratio of at least 1.5 in the relation of past average operating earnings to postfinancing annual interest and sinking fund charges. Other ratios (total debt to cash earnings available for interest, term debt to fixed assets, current assets to current liabilities) may also be considered important.

The borrowers must expect to have restrictions imposed with respect to executive salaries and expense accounts. If the loan is an unsecured loan, it may be expected that mortgages and liens will be prohibited, with specified exceptions, in order that the company may not mortgage its property to the detriment of the unsecured lender. Dividends may be prohibited; and minimum working capital and maximum permissible borrowings may be specified. Restrictions on working capital, borrowings, liens, asset acquisitions, and other similar matters must be carefully screened, so as not to hamper the company's growth. Restrictive clauses, as well as interest rate and principal amount, lend themselves to some "horse-trading."

Development of the loan presentation requires time and effort, as well as expense. Financial data for ten to twenty years will be required. The purposes of the loan must be carefully worked out in collaboration with the borrower's accountants. Market surveys and engineering studies may be useful. In comparing the cost of the insurance loan with the cost of the public offering, the expense of this examination must be taken into account. Private placement costs may also include finder's or loan broker's fees, as well as legal, accounting, and printing costs.

The private placement has certain advantages over the public offering. Negotiations are direct with the lender, so that the deal can be tailor-made. Furthermore, at a time when public markets may be volatile, the commitment of an institution will be more secure than the prospect of proceeds of a public offering. Also, some companies which do not meet the public requirements of growth potential may find a more sympathetic response in the institutional lender. And in the event of a default or need for variation in terms, modifications of the contract may be simpler than in the case of publicly-held debt. ${ }^{31}$ The out-of-pocket costs of a private placement are usually somewhat less than those of a public offering. Registration costs are saved, and legal, accounting, and printing costs are reduced.

Summarizing, institutional loans can be a source of long-term loans to a part of the small business community. Insurance companies vary greatly, but a number of them will consider loans as small as $\$ 250,000$, and several will consider loans in the area of $\$ 100,000$ or below. Usually, acceptable borrowers will have net worths not less than $\$ 250,000$ to $\$ 350,000$. Management, type of business, nature of product, and other similar factors will have an important bearing on the treatment of the loan application. Costs will be less than those encountered in the case of public offering. Some insurance companies are interested in inflation hedges, but none will accept such features as justification for a loan to an undercapitalized borrower.

"Cf. 2 Dewing, op. cit. supra note 13 , at III2. 


\section{$\mathrm{V}$}

\section{SOURCes of Funds: The Public OfFering ${ }^{32}$}

Public securities offerings of small businesses are usually in some form of stock or in bonds convertible into stock (or with stock warrants attached). Combinations of stock and debentures or mortgage bonds may also be salable, but in general, the small business has only limited access to the public corporate debt market, as such. Investors view the small business company primarily as a source of equity investment for capital gain.

\section{A. Advantages of Public Offering}

The primary reason for a public securities offering is to raise funds for the operations or expansion of the issuer. ("Secondary offerings" by stockholders in the first instance, before a public market has been established, are not viewed with favor by many underwriters, although the exceptional case recurs. At times, a combination primary and secondary offering may be made.) In addition to obtaining capital, there are other advantages to be realized by a public offering. The establishment of a market is of advantage to the company's credit, as well as to its stockholders who may desire to improve the liquidity of their holdings. ${ }^{33}$ At times, securities can be sold to the public on terms and at prices more favorable than those available in a private offering.

Furthermore, a company with public stockholders may be controlled by management with substantially less than a majority position. In addition, once a public market is established, the company will be able (except at times of stress or unfavorable operating results) to raise funds more easily than before.

\section{B. Size and Nature of the Issuer}

Attractive growth companies, with recent average annual net earnings not less than $\$ 100,000$ to $\$ 150,000$ and net worths above the $\$ 400,000-\$ 500,000$ level, are the issuers of most of the better small offerings, but in some instances (particularly in the Regulation $\mathrm{A}$ offering described below), net worths and earnings are smaller than those amounts. Earnings, in fact, vary widely; at times, an absence of earnings, or a loss, does not prevent an offering. Size of total assets is not a discernible standard.

Fads in industries, as well as in types of securities, are apparent. Economic or financial developments, from time to time, increase the popularity of one industry or another; and such developments are often reflected in the public offering statistics.

\footnotetext{
${ }^{32}$ The discussion in this section is based in part on an analysis of about 350 prospectuses for issues (other than those of utilities) under $\$ 3,500,000$ sold during the period $1956-58$, constituting substantially all the issues of that size advertised during that period in the Wall Street Journal and Investment Dealers Digest. Reference has also been made to I DewiNG, op. cit. supra note I3, at 290-308; 2 id. at Iorg-140; George J. Leness, et Az., New MONeX for Business (1956); FoulKe, op. cit. stpra note 8. The discussion relates to nonutility companies.

${ }^{33}$ Recent amendments to the tax statutes permit payment of inheritance taxes over a I0-year period, which may reduce the pressure by stockholders for marketability. INT. REv. Cope of 1954, \$ 6r66.
} 
But analysis of successful offerings indicates that few, if any, legitimate industries or types of companies are to be deemed excluded from the market if the issuers possess the right combination of attractive features signalling growth potential.

\section{Approaching the Underwriters}

To the inexperienced, the financial community may appear to be a monolithic structure, operating more or less efficiently to transmit public investment to the users of capital. Under the microscope, however, it resembles an anthill, alive with thousands of ants, different in size, color, and function. "Wall Street," as a description of the nation's financial center, consists of intermediaries and lenders, banks and brokerage houses, and numerous other specialists in the financial business, functioning from coast to coast. There are almost 4,000 firms of securities brokers and dealers, most of which specialize in various functions or types of securities or issuers. The New York Stock Exchange has I,348 regular members, of which perhaps half or less represent the "wire houses," or major securities brokers as the public knows them. These same firms constitute the bulk of the 499 regular members of the American Stock Exchange. Several well-known underwriting firms are not members of any exchanges.

For our purposes, securities dealers or brokerage houses may be divided among (I) the trading houses, (2) the firms primarily interested in wholesale or retail distribution of "seasoned" issues or issues originated by others (including firms that specialize in mutual funds or investment company securities) and (3) firms which originate issues (and which may also function as trading or distribution houses). Many houses are interested only in bond distributions; others will not sell the securities of a company below a certain minimum size which may, in fact, be quite substantial from the viewpoint of the small businessman; and still others specialize in securities of one or more specified industries (e.g., chemicals, rails, etc.). Many securities firms of excellent repute and substantial size are interested in small business growth situations.

The underwriter who originates and distributes new issues is a securities merchant. It is his function to package the security in an attractive package and find the right buyers. The successful underwriting firm performs a function similar to that of the lending institution-it culls out the inappropriate and prepares the appropriate issues for public sale. It assists in transforming public savings into business capital.

A proposed offering must compare favorably with similar issues previously marketed if it is to be received sympathetically. The underwriter will examine the proposal to determine whether the offering is of the kind and size that his customers (and those of his associates) will purchase, and whether the time is ripe for marketing the issue. The presentation must include data to indicate the adequacy of the financing sought. Underfinancing must be avoided, since it may leave the company 
without funds to realize its goal at a time when other funds may not be available. Overfinancing may render the issuer unable to earn a fair return on its total capital.

Once the underwriter has determined to originate, or buy the issue, "horse trading" results, leading to an understanding on the kind, price, and amount of securities, the underwriting discount, and many other matters. The underwriter will insist on collaborating with the company and its advisors in designing the right capital structure for the company's needs.

\section{Valuation of the Enterprise; Price-Earnings Ratios}

In order to determine the price of the stock (or the conversion price of bonds), as well as the division between the public and the "inside" stockholders, the issuer must be evaluated. In no aspect of the transaction will there be wider disagreement than in the valuation of the enterprise. A practical solution of the problem may be accepted by the company's management as part of a broader agreement; but often the difference in point of view persists permanently. A part of the difficulty stems from the differences in experience, standpoint, and approach. The businessman who has spent a number of years in the development of the enterprise has a feeling for his business that few can share. The underwriter and the institutional loan officer, who evaluate businesses as a part of the everyday transaction of their affairs, operate largely by financial rules, concepts, standards, and judgments, not always capable of articulation, which the businessman usually does not understand.

Fundamentally, the value of a share of stock lies in the participation which it affords in the future earnings of the company. ${ }^{34}$ The investor in the going concern does not intend to purchase a part of an enterprise to be liquidated, ${ }^{35}$ or of real estate or other physical assets. Hence, book values, good will, plant condition, and similar factors which the owner of the enterprise may consider of great importance are not principal criteria for determining the value of the going enterprise; they are of significance only, or primarily, in their relationship to future profits. ${ }^{36}$

Different views may be taken of earnings and values for different purposes. The sale of an entire business may be based on one set of standards; the sale of a minority bloc of stock may be based on another; and the sale of a controlling interest on a third. The persons who buy a going concern, "lock, stock, and barrel," will value it, in part, in terms of their own conditions and the special emoluments they anticipate. Cost savings, overhead reduction, loss tax-credits, salaries, and other items may have an important effect on estimated earnings, and hence on the price they are willing to pay. A company engaged in expansion for diversification or production integration may, at times, put a higher valuation on the enterprise than the public. On the other hand, a knowledgeable buyer may be unwilling to accept the public appraisal.

The past record is important primarily as an indication of trends and future

${ }^{34}$ Cf. I Dewing, op. cit. supra note 13 , at 287 .

so Although, on occasion, this type of investment is sold.

${ }^{86}$ Benjamin Graham \& David L. Dodd, Security Analysis 429, 491 (1934). 
earnings. By itself, however, it is not the basis for sound conclusions as to earnings potentials. These can be guessed at only after an examination of all important aspects of the business, including other financial data.

In connection with the determination of past earnings, the calibre of the company's accounting department and the policy underlying the keeping of its records are important. To the small businessman on his way up, accounting records may not be a major concern, except as a basis for tax reports and collection of accounts. Overliberal attitudes toward expenses and overconservative attitudes toward assets and income lead to problems in appraisal of earnings and differences of opinions as to the true earnings potential of the company. Auditors will be bound by facts then available, and the underwriters will relate their thinking to earnings as certified by reputable auditors. They will usually not make allowance for asserted earnings, unless reflected in data usable in the offering prospectus.

Undoubtedly the most important single factor in, the determination of potential earnings and in the estimate of value of the usual small business-manufacturing, finance, service, etc.-is the calibre of management. Small companies are relatively speculative. They are valuable because of growth potential, which, in turn, is dependent, in good part, on the ability of management. Management may be more important in that type situation than in the case of an enterprise, such as a water company, where earnings are dependent to a larger extent on fixed assets and monopoly position. Other factors affecting the determination of future earnings would be, principally, stability of the market for the company's product (welladvertised brands vs. unbranded merchandise), patent structure, area limitations and dependence on local economic conditions, position of the enterprise vis-à-vis competition (including consideration of product development research policies), labor conditions, and general economic potential.

When the potential average earnings in the proximate future have been determined, the value of those earnings is estimated by applying a ratio or factor. For example, a company with earnings (after taxes) of \$100,000 may have a value of $\$ 600,000$. The ratio of earnings to value is $6: \mathrm{I}$ in such case. To this valuation of earnings, modifications or adjustments may be applied for special circumstances. Nonearning assets, or excess working capital must be evaluated. Under or overcapitalization must be considered in relation to prospective returns. The final result is the value of the enterprise for purpose of public offering or private investment. Price per share is an arithmetical derivative of the valuation.

The price-earnings ratio may vary from time to time and industry to industry. It is a reflection of the estimate of the evaluator of a fair investment return at that time and the risk involved in obtaining such a return from that enterprise. The ratio may reflect general thinking in the financial community as well as comparison with the price-earnings ratios of similar companies. A "seasoned" stock, even with characteristics similar to those of the new company, may command a higher price 
in the market, and appropriate adjustments must be made for the difference in situation.

While the appraisal is, in good part, a personal determination of the proposed underwriter, it is made with a view to public acceptance of the security to be sold. Such acceptance will be influenced by the estimates of analysts and advisors in the firms, institutions, and others who may be called upon to participate in the distribution. They are familiar with the basic concepts and standards which guide the underwriter; and each will make his own appraisal of the investment value of the security.

Almost by definition, price-earnings ratios do not lend themselves to generalization. Higher ratios (higher prices) are sometimes found for smaller companies than for those larger in asset size. The ratios will vary from issuer to issuer, even at the same point of time. A comparison of five issues sold within a few weeks of each other by well-regarded, top-flight underwriters in the fall of $195^{8}$ illustrates the variations. The issuing companies had net worths of $\$ 360,000, \$ 1,250,000, \$ 1,400,000$, $\$ 2,000,000$, and $\$ 3,000,000$, respectively; and indicated current annual earnings (after income taxes) in the area of $\$ 100,000, \$ 300,000, \$ 800,000, \$ 400,000$, and $\$ 600,000$, respectively. The companies were engaged in the manufacture of electronic items, chemicals, medical equipment, and building items. Price-earnings ratios (in relation principally to current earnings) ranged from 5:I to 18 or $20: x$. The smallest company (electronics), with the most limited earnings record, obtained the highest price for its stock; the largest (medical equipment) obtained an intermediate price; and an intermediate-sized company, the lowest price. If three years' average earnings were used as a base, the spread was from 5:I to almost 50:r. A similar analysis of a group of companies in January 1959 revealed the same striking differences. The ratio of current or recent earnings to offering prices is not, of course, a reflection of the full valuation formula. In each case, there were presumably various reasons for the ratio and resulting price-reasons which others might weigh differently. However, rules-of-thumb by authoritative writers, using ratios of four to $81 / 3$ times (twelve to twenty-five per cent or higher returns), ${ }^{37}$ depending on degree of risk, are subject to question. Ratios of eight to twelve times used by the Securities and Exchange Commission in its evaluation of enterprises (other than electric and gas utilities) for reorganization purposes ${ }^{38}$ reflect the conservative approach of the financial expert for reorganization purposes, and not necessarily the attitude of the businessman who runs as he reads and who is dealing with growth and optimism.

\section{E. Interest Coverage and Size of Issue}

Variations in interest coverage of bond issues are also substantial. Interest coverage of a finance company issue may be as low as 1.2 times; for a manufacturing

${ }^{37}$ I DEWING, op. cit. supra note 13 , at 388 et seq.

${ }^{88}$ See In re Northeastern Steel (1957), Corp. Reorg. Release 107 (8 times); In re Muntz TV, Inc. (1955), Corp. Reorg. Release 95 (81/3 times); In re Chicago and West Towns Ry., Inc. (1953), Corp. Reorg. Release 92 (121/2 times). 
company, it may be ten times. As to size of issue (stock or bonds), most underwriting houses object to offerings in an amount in excess of the then capital structure, but there are numerous exceptions.

\section{F. Costs}

There are three elements of cost to the seller of the issue: (I) compensation to investors, (2) compensation to underwriters, and (3) other expenses (professional fees, printing costs, and the like). In the case of term financing, the largest cost is the interest paid to investors. Compared to that cost, initial distribution charges are not of major significance, when spread over the life of the issue. For example, a relatively high initial cost of fifteen per cent for distribution of a fifteen-year bond issue adds only one per cent to the average interest cost. A saving in the indicated coupon rate, as compared with other similar issues, may, in fact, make the issue a low-cost rather than a high-cost offering. ${ }^{39}$ Total costs will depend more on the timing of the issue and money rates than on out-of-pocket expenses, and may vary drastically, from time to time, in relation to economic swings.

The true cost to the issuer of stock issues (and certain securities convertible into stock) is the difference between the "fair market value" of the stock sold and the net proceeds per share received by the issuer (or the selling stockholder). "Fair market value" may be best defined for this purpose as the price at which a willing, well-informed buyer and an equally willing and well-informed seller will consummate a sale.

Where the issuer receives a higher net price (after all costs) than accepted value standards would entitle him to, it may be contended that the cost of the distribution is borne by the investor, not the seller. Conversely, of course, an underpriced stock may be excessively costly to the seller, even though underwriting charges and other costs per dollar of proceeds are at the lowest end of the scale. Hence, analyses and comparisons of securities costs are not precise. The speculative tenor of the market, passing market fads, and changing economic and financial factors will have a significant bearing on the current dollar cost to the seller.

Public distribution costs of registered issues have been surveyed by the Securities and Exchange Commission. The data in table four, for selected years in the period from $195^{I}$ to 1955 , indicate that by percentages of total proceeds, distribution costs are greater for the smaller issuer than for the larger, for stock issues than for bond offerings, and for manufacturing and mining companies than for utilities. ${ }^{40}$

\footnotetext{
${ }^{80}$ E.g., in September 1958 , Sears Roebuck and Company sold $\$ 350,000,000$ of 25 -year debentures at an underwriting cost of $7 / 8 \%$. Within a few weeks, the issue was selling at a $5 \%$ premium. It is arguable that the issue was underpriced and that the cost was extraordinarily high as compared with other issues at the same general time.

${ }^{10}$ Sec Federal Reserve Report 298. A resurvey in 1957 appeared to indicate somewhat lower percentage costs at the lower end of the size scale, but the sampling was small and conditions were dissimilar, so that the comparison is of doubtful validity. The decrease in the high-cost uranium issues and high market levels may have been contributing factors.
} 


\section{TABLE IV}

Comparison Within INDUSTry-Issuer Groups of Cost of Flotation of

Registered Securities

BY TYPE AND SIZE OF ISSUE

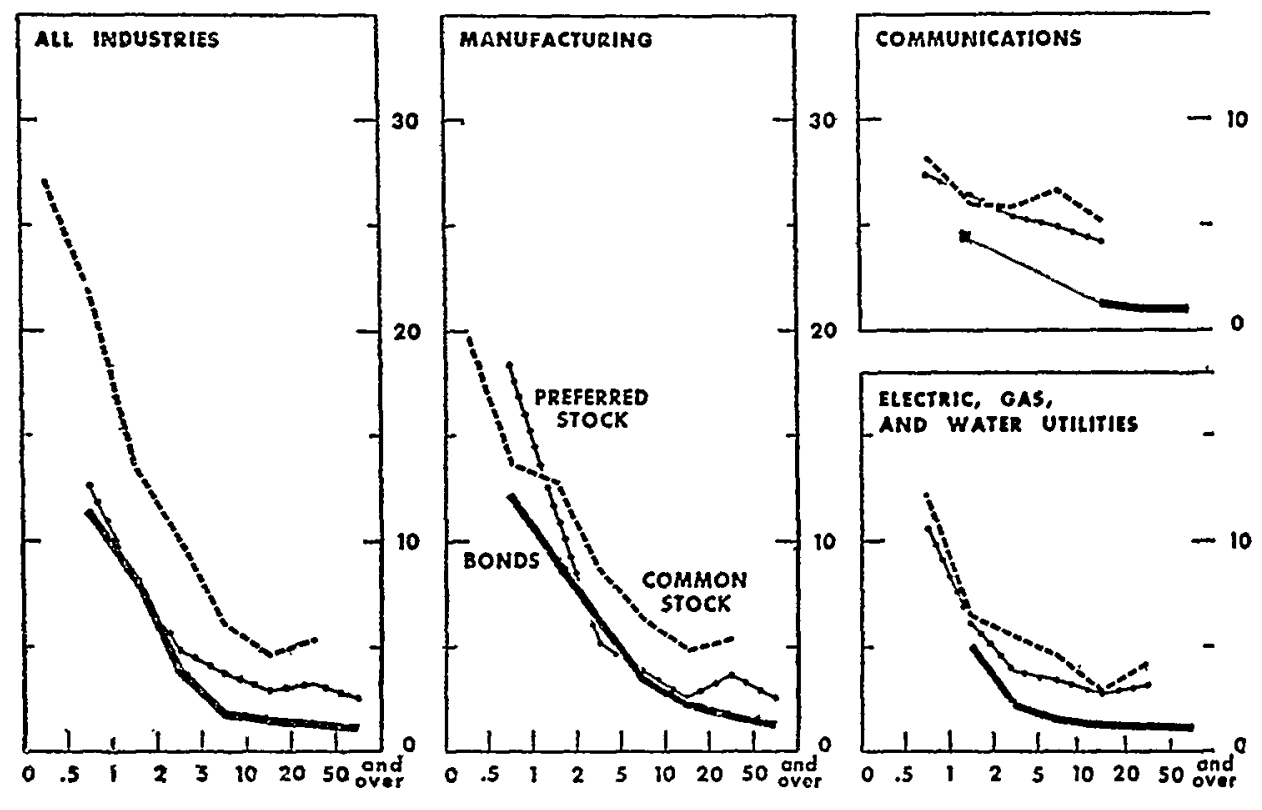

SIZE OF ISSUE-MILLIONS OF DOLLARS

Note: Average cost of registered securities offered to the general public through investment bankers in I95I, 1953, and 1955 .

Sources: SEC, Cost of Flotation of Corporate Securuties, 195I-1955 (I957); Federal Reserve System, 85th Cong., 2d Sess., Financing Small Business 290 (Comm. Print 1958).

A similar survey by the Securities and Exchange Commission of average underwriting cost during the $195 \mathrm{I}-55$ period revealed the data in table five.

An examination of prospectuses in 1958 for issuers with net worths in the $\$ 1,000,000-\$ 3,000,000$ class disclosed underwriting commissions, in general, of from seven to fifteen per cent for stock issues, and from five to ten per cent for debt issues (usually convertible debentures or unit offerings). A similar examination of prospectuses for 1956 and 1957 indicated the same spreads, but there were numerous exceptions in each year. A survey of issues in the $\$ 300,000$ class (Regulation $A$ issues, discussed below-not including small issues by large companies or those with established markets) indicated underwriting commissions ranging from ten to twenty per cent, with most issues in the fifteen-to-twenty per cent class. ${ }^{41}$ In all periods referred to, compensation to the underwriters in the form of stock or options have not been considered because of statistical difficulties. Such compensation is, at times, of importance.

¿2 A survey by the Securities and Exchange Commission of Reg. A costs in the $1951-55$ period appeared to indicate that total percentage costs were less than those of some registered issues, but the sampling is small and the statistics are open to question. Cf. Federal Reserve Report 299. 


\section{TABLE V}

Compensation to Underwriters for Selling Registered Securuties BY INDUSTRY-ISSUER GROUP AND SIZE OF ISSUE

Compensation as percentage of total flotation costs
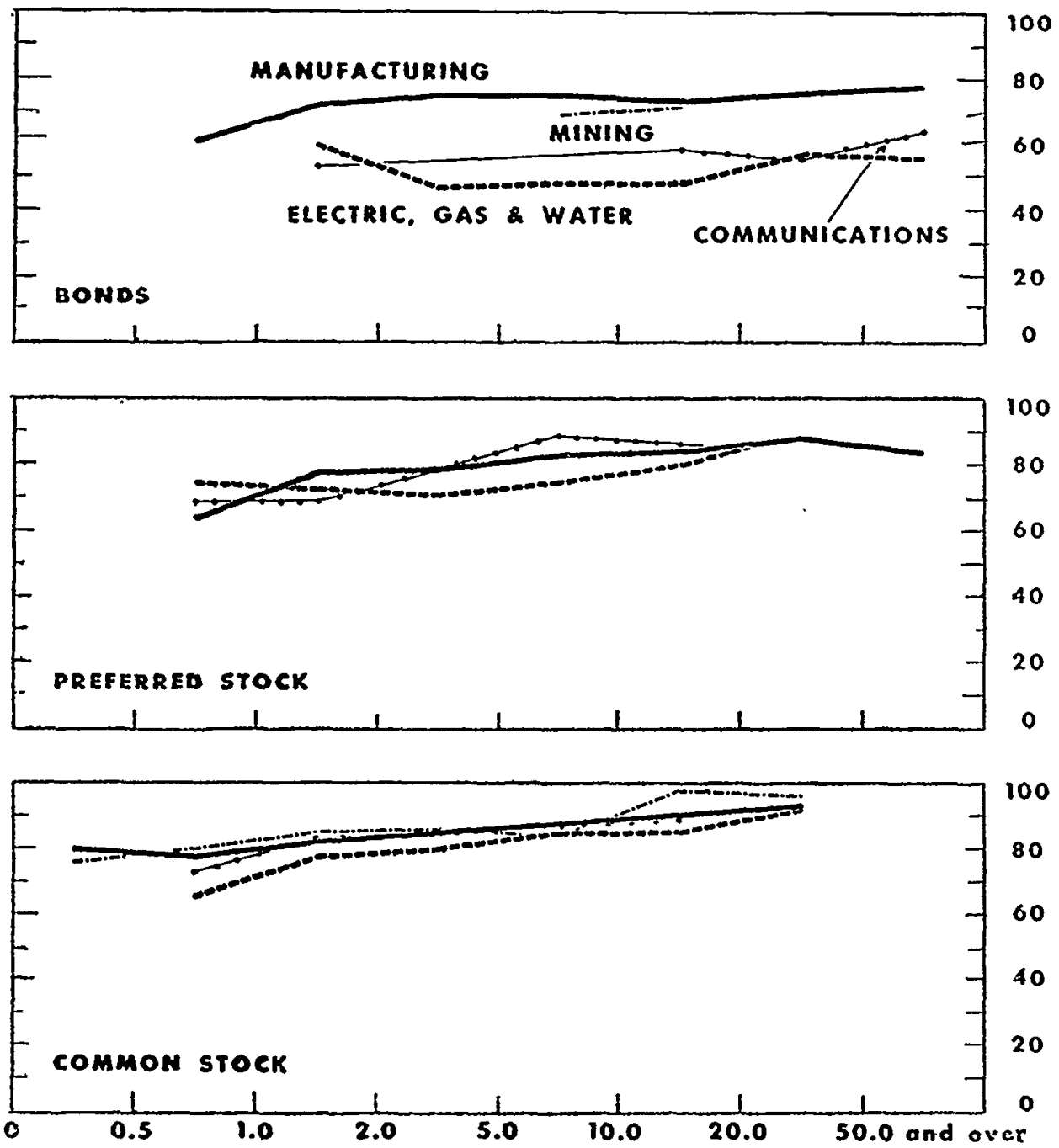

SIZE OF ISSUE-MILLIONS OF DOLLARS

Sources: SEC, Cost of Flotation of Corporate Securities, i951-I955 (1957); Federaz Reserve System, 85th Cong., 2d Sess., Financing Smazi Business 294 (Comm. Print 1958).

Variations in rates are accounted for, in part, by timing and the type of issue and issuer. Difficulty of distribution is also a factor in costs. Underwriters contend that new issues of small companies are more difficult to sell than accepted issues in varying degrees, and that to induce dealers and salesmen to engage in the distribution of the unseasoned issue rather than the more easily sold mutual funds and other seasoned issues, it is necessary to compensate them on a competitive basis. 
Variations in underwriting rates may be dependent on other factors, as well. A market glut of new issues will force underwriting rates up. On the other hand, at a time when the market is involved in a speculative surge and competition for good issues is keen, good trading and knowledge of available sources can often result in a saving of underwriting costs.

Other costs include, principally, professional fees and printing costs, and vary from case to case, depending on the work required. The work involved does not relate to the size of the issue. Such costs may be six or seven per cent for the $\$ 500,000$ to $\$ 600,000$ issue, four or five per cent for the million-dollar issue, and proportionately less as the size of the issue increases. Professional fees in substantial amount often result from the necessity for setting the issuer's house in order, a service required in any event and related to the public offering only in point of time.

\section{G. Underwriting Agreement}

Having negotiated the terms of the financing and the price of the security (the definitive offering price is usually agreed upon at the last moment before offering), the parties and counsel, principally the latter, develop the terms of the relatively complicated "underwriting agreement." Preparation of the necessary audit, legal and offering documents, registration statement, and other reports, together with the period required for registration under Securities Act and state "blue sky" laws, will consume two or three months or more. During that period of time, although there will be an understanding on the details of the transaction, no agreement will be signed, or in any event, no legal liability will be assumed by the underwriter. Only when the securities are available for delivery will the underwriter agree to purchase them. The closing or payment date will usually follow the public offering by a few days; the public offering will usually be made as soon as possible after the effective date of the registration statement.

The practice and policy of underwriting houses not to commit themselves until immediately prior to the public offering is uniform and well-established among substantially all underwriting firms. The underwriters contend that financial markets are so volatile that no underwriter can agree to stand by for the duration of the preparation period. An issue is negotiated against the background of specific economic and financial conditions. Price and terms are set in that context. The underwriter has no way to hedge such a commitment, as is done in many other fields. Finally, all brokers and dealers must maintain a prescribed ratio of net worth to total obligations. Accordingly, they refuse or are unable to immobilize substantial amounts of capital for long periods.

In any event, the prospective issuer will find that he must undertake the preparation of the issue without a binding contract for the sale of the issue until just before the public offering date. However, the issuer's prospective "exposure" to expense before offering is usually not an item of major size; it is determinable and can be circumscribed within reasonable limits. The issuer may often rely on the moral 
obligation and economic incentive of the underwriter to complete the issue, if possible. The reputable house will make the offering under any but the most adverse circumstances, even to the point of losing its profit or sustaining a minor loss, in order to prevent a fiasco. An unsuccessful transaction is a blot on the reputation of the underwriting firm; and it will also be out of pocket if the issue fails.

Underwriting contracts vary in tenor from the commitment which becomes firm on signature of the contract, subject only to a holocaust, such as war, etc., to the contract at the other end of the scale, the "best efforts" agreement, which does little more than obligate the underwriter to use his "best efforts" to sell such part of the issue as he can. In the case of the weakest "commitment," the underwriter must, in any event, purchase all, or a specified portion, of the issue, if he is to purchase any; in the "best efforts" agreement, the underwriter may "take down" whatever he sells, and there is no penalty for failure to sell all or any substantial part of the issue. A "best efforts" agreement may be justified where the record of performance of the underwriting house is good, but its capital is limited, and where, as in the case of a finance company, any significant portion of the offering can be put to use profitably. It should not be used where a minimum amount of proceeds is essential for the issuer's program.

Although the issuer will deal with only one underwriter, often the underwriter will not distribute the issue by himself. In the "commitment" transaction, he will usually form a syndicate or a group of underwriters. The underwriting agreement will be so drafted that each member of the syndicate agrees directly to acquire a specified portion of the issue.

In addition to the commitment or "best efforts" clauses, the underwriting agreement is a complex structure containing many other provisions. It prescribes the kind of security to be sold, the selling period or consummation date, and the underwriting discount to be paid. It includes representations by the company as to its corporate structure, condition and financial data, an undertaking to prepare and file a registration statement which shall be accurate, agreements by the company to indemnify the underwriter (and by the underwriter, to indemnify the company) against misrepresentations in the prospectus, agreements for payment of expenses (the issuer usually pays the fees of the counsel for the underwriter), covenants with respect to qualification under "blue sky" laws, and many other items. Salary and dividend limitations may be required to make the issue marketable. As a usual matter, the underwriter will reserve the right of preference or first refusal in connection with future sales of securities, public and/or private, and the agreement will provide that the underwriter shall be entitled to representation on the board of directors and to receive current financial and other data with respect to the company. On occasion, the underwriting agreement provides that the underwriter shall receive options or warrants (but this may not be permissible in certain states). During the period of the public offering, and usually for a number of months thereafter, the company and its principal stockholders may be required to agree not to sell any 
stock or other securities to the public (and at times, privately) without the consent of the underwriter.

\section{VI}

\section{Preparing the Issue for Market}

Once there is general agreement on the terms of proposed offering, the company and its professional advisors must turn their attention to the requirements of the Securities Act of $I 933$ and applicable state securities regulation statutes ("blue sky" laws). 'The Securities Act of 1933 requires, in substance, that any issue sold in interstate commerce must be registered unless the transactions or the securities are exempt. $^{42}$

\section{A. Private Offerings}

Transactions involving institutional or other private investors can usually be brought within the exemption provided by section 4(I) of the Securities Act of 1933 for priyate transactions. ${ }^{43}$ Whether or not a particular transaction is exempt must be carefully examined by counsel. The exemption may depend not on the number of persons involved, but on the nature of the transaction. ${ }^{44}$

\section{B. Local Offerings}

Restricted local public offerings may also be made, without registration, to persons resident within a single state or territory, where the corporation is incorporated by and doing business within such state or territory. ${ }^{45}$

In such case, it is important that the investors be residents of the state of incorporation and that their purchases be for their own accounts and not for nonresidents. A sale of part of the issue to a single person not a resident of the state will void the exemption. Most issuers have found it necessary to obtain written assurances of residence and investment intention. An offering may not be begun locally and then expanded. If a local offering and an interstate offering are so connected, or "integrated," as to constitute, in fact, one offering, the exemption will not be available. Once the issue has been sold, however, in a manner consistent with the exemption, a subsequent bona fide transaction by the investor will not void the exemption.

The advantage of the exemption relates primarily to costs; no registration statement is required to be prepared. However, few offerings can be accomplished without any prospectus, and when the prospectus is prepared, it must be as carefully devised as any other document used to solicit public subscription. Misrepresentations in such documents fall within the prohibitions of the Securities Act of r933, notwithstanding the exemptions. ${ }^{48}$ A result of such exempt offerings will be a high con-

\footnotetext{
1248 STAT. 74, I5 U.S.C. \$77a et seq. (1952).

${ }^{4}{ }_{4} 8$ Stat. 77, I5 U.S.C. $\$ 77 d(I)$ (1952). See Louis Loss, Securiries Regulation 394 (I951).

4t See In re Gilligan, Will \& Co., Securities and Exchange Act Release No. 5689, May 7, 1958.

${ }^{45}$ Securities Act of I933, $\$ 3(\mathrm{a})(\mathrm{II}), 48$ StAT. 75-76, as amended, I5 U.S.C. $\$ 77 \mathrm{C}(\mathrm{a})$ (II) (1952).

${ }^{46} \mathrm{Cf}$. Securities Act of $1933, \$ \$ 12(2), 17,48$ STAT. $84-85,15$ U.S.C. $\$ 771$, q (1952).
} 
centration of stockholders immediately adjacent to the company's principal operating area.

\section{Regulation A}

A more important exemption is to be found in section $3(\mathrm{~b})$ of the statute. ${ }^{47}$ That section permits the Securities and Exchange Commission, by regulation, to exempt issues not exceeding $\$ 300,000$ in total offering price. The section was enacted to permit exemption of offerings so limited in character or amount that registration was not considered necessary in the public interest and for the protection of investors. ${ }^{48}$ The exemption was intended to be used sparingly and to provide more flexibility in the area of issues which were almost, but not quite, intrastate or nonpublic. ${ }^{49}$ The exemption originally covered $\$ 100,000$, but was increased in 1945 to $\$ 300,000$.

Prior to 1953, practically no data were required to be used. However, if offering circulars were used they were required to contain a few items of information and to be filed with the Securities and Exchange Commission. In 1953, the regulation was changed to require certain disclosures as a condition of the exemption. In 1956 , the regulation was further amended to impose additional requirements on those using the regulation.

At present, Regulation $A$ is available for offerings not exceeding $\$ 300,000$ by issuers, and not exceeding $\$ 100,000$ by controlling persons. Amounts up to $\$ 50,000$ may be sold (except in certain cases) without the use of an offering circular, but data similar to that required in an offering circular (except for financial data) must be filed with the Securities and Exchange Commission. Offerings above $\$ 50,000$ require the use of an offering circular, including some financial data which need not be certified. ${ }^{50}$

Although such Regulation A offerings are often called "short form registrations," they are not registrations. The examination procedures and required data are substantially different. The Regulation $\mathrm{A}$ documents are examined by regional offices of the Securities and Exchange Commission rather than by the Washington office. The regulations require a ten-day filing period instead of the twenty-day minimum registration period, but substantially longer than that is often required. Actually, there is no clearance or similar procedure. The procedure is rather informal, and quite time-consuming. Requirements may change from regional office to office, although the Commission has attempted to coordinate examination procedures by establishing a special group in Washington to review practices.

The original purpose of Regulation A to provide a method for offering small issues more cheaply, more quickly, and more favorably than in the case of registered issues has not been realized in many cases. The only difference in out-of-pocket

\footnotetext{
${ }^{47} 48$ STAT. 76-77, as amended, I5 U.S.C. $\$ 77 c($ b) (1952).

${ }^{28}$ House Committee on Interstate and Foreign Commerce, Federal Supervision of Traffic in Investment Securities in Interstate Commerce, H.R. REp. No. 85, 73d Cong., Ist Sess. I5 (1933).

${ }^{10}$ The Commission was to observe "the prima facie requirement that every security and transaction not specifically exempted by the terms of the bill should be kept within its scope." Id. at 6-7.

${ }^{5}$ I CCH FED. BanKING L. REP. 218I et seq.
} 
costs between Regulation $A$ and registered issues may be a small reduction in printing charges and perhaps in legal fees. The total cost of a Regulation A offering, considering the underwriting charges often applied to such cases, is probably little less than the cost of a registration statement economically handled.

As against this saving, issuers may find their choice of underwriters restricted. Although the Regulation is merely the avenue, and not the vehicle, many underwriting firms feel that the use of Regulation A creates the impression of failure to meet conservative standards. Such an impression may often be unjustified, but the extraordinary use heretofore of the Regulation for highly speculative and unsound offerings has created that impression. The type of underwriting arrangements ("best efforts") usually encountered in such cases and the fact that many issues were only partly sold or not sold at all are also contributing factors in the current attitude toward Regulation A.

The imposition of higher disclosure standards and the current attitude mentioned above reduced the former widespread attraction of the Regulation for many issuers. From a total of $\$ 176,000,000$ of prospective offerings filed under Regulation $A$ in 1956 (involving approximately I,500 separate offerings), filings under the Regulation fell to \$II4,433,000 in I957; and during the first six months of $195^{8}$, they were about twenty per cent below the same period in $1957 .^{51}$ Nevertheless, on occasion, Regulation A may still be conveniently and satisfactorily used for local or quasi-public issues not exceeding $\$ 300,000$ in aggregate ultimate offering price. ${ }^{52}$

The preparation of an offering circular and notification statement under Regulation A requires considerable care. Counsel will usually advise the client to include a fully certified balance sheet and three years' profit and loss statement, together with many of the items required in registration statements, even though the Regulation permits less.

After an examination period, which may last from two to four weeks, the company and its underwriter are then in a position to make a public offering. At the end of each six months, there must be a report made as to the amount of securities sold.

\section{Registration Statement}

Registration under the Securities Act is accomplished by a registration statement, which is filed with the Securities and Exchange Commission. The Commission has developed an effective registration procedure based on a quarter century of experience. At the present time, issuers past the development stage (with the exception of major companies issuing only debt) must use Registration Form S-I. The registration statement consists of three principal parts: (I) the prospectus, (2) part two, giving certain supplemental data, and (3) voluminous exhibits. The prospectus requires the inclusion of data concerning the underwriting and costs, use of the proceeds, capital

s2 SEC, Statistical Bulletins, April and May, 1958.

${ }^{52}$ Note, Federal Control Over Small Isstes of Securities, yo HARv. L. Rev. 1438 (1957); 13 Bus. Law. 303 (1958). 
structure, and balance sheet as of a date within ninety days (if not certified, then an additional balance sheet as of the close of the prior fiscal year), together with profit and loss data for a five-year period, if the company has that much record. Many underwriters will request disclosure of a longer record of earnings, if available. Financial data must be certified in accordance with regulations of the Commission by an independent public accountant.53

The financial data are subject to rather extensive regulations, which require the filing of supporting schedules. Other exhibits required to be filed include the charter, bylaws, important contracts, underwriting agreement, patents, reorganization plans, voting trust agreement, pension or retirement agreements, and other items of significance. Although the Commission's rules do not require the printing of the documents for filing, it has been the practice uniformly to print the entire registration statement. In the case of the smaller issues, costs can be reduced by using processes other than printing for those parts of the registration statement which are not required to be distributed to the public in quantity. The prospectus, however, which must be distributed to the public, will usually be required by the underwriter to be printed.

Usually, appraisals and forecasts of earnings may not be the basis of representations in the prospectus. On occasion, however, an underwriter may require an independent market survey or an examination of the company by an independent engineering firm and may ask for independent professional earnings' projections to corroborate his own estimate of a company's growth potential. Factual data thus obtained are useful as background data in drafting the registration statement.

The issuer's principal executives may find it necessary to devote considerable time to a survey of their business, its growth potential, its financial needs, and many other items. Such a survey, however, may be necessary whatever the source of the external capital.

Upon filing of the registration statement, the Securities and Exchange Commission will advise the issuer as to additional data the staff may consider essential. The "Letter of Comments" setting forth the data required or the corrections deemed necessary may be forthcoming in two weeks, more or less, after filing. An additional two weeks or more will usually be required to conclude the registration process.

During this registration period, the underwriter is permitted to organize his "syndicate" and selling group of other participating underwriters and dealers, and to distribute a preliminary prospectus (referred to as the "red herring"). However, no orders may be confirmed until the effective date of the registration statement, and then only with a prospectus or after a final prospectus has been distributed.

Since the adoption of the Securities Act in I933, complaint has often been heard that the Securities Act seriously impedes the financing of small business. Some impediment must, of course, be recognized. A registration statement must be prepared

ts The SEC will usually not consider an auditor to be independent if he had any direct financial interest or any material indirect financial interest in the issuer or affiliates, or if he was an officer, director. etc., during the period under review. Cf. Rule 2.01, Reg. S-X. 
and filed, and during the period of its examination the issue may not be sold. It is the latter aspect of the case which poses difficulty, since during this examination period, market conditions may change. However, that risk is as much a risk of the large company as it is of the small company. It has long since been accepted that this much risk and inconvenience are justified by the greater benefit to the investor. It is doubtful that any less data would now be required by most underwriters, even if there were no Securities Act of r933.

\section{E. "Blue Sky" Laws"}

In addition to the Securities Act of 1933 , the company must observe the requirements of state securities statutes. Generally, in the area from Maine to Virginia, the requirements of the state laws are not onerous. More work is required in the case of Vermont, where a type of statute similar to that to be found in the Southeast and Midwest exists.

In the latter sections of the country, regulatory statutes sometimes pose more difficulty. The company with three to five years of earnings, meeting specified return formulae, will usually be permitted to "register by notification," which, in substance, permits satisfaction of requirements by the filing of a copy of the federal registration statement and certain supplementary data. In a few states, securities may be qualified by "coordination" or "description," which requires, in substance, only the filing of the federal prospectus and a few other documents, without regard to earnings and similar standards. Where the issuer is unable to meet the requirements for registration by coordination or notification, more extensive filings will be required. Underwriting costs of stock issues are limited in some states to fifteen per cent. Several states provide that no warrants may be given to the underwriter or officers unless similar warrants are sold to the public. In a few instances, appraisals or similar supplementary data may be necessary.

\section{VII}

\section{Postfinancing Problems}

When the issue is sold, the underwriter or the institution and the company will meet at a "closing," at which the numerous documents covering the necessary representations, warranties, covenants, etc. will be exchanged. The underwriter or insurance company will pay for the securities and receive delivery of them. After mutual congratulations have been extended and the parties return to their everyday business, problems arise. The company's officers find it necessary to adjust their thinking to the company's status as a public company. The initial period of living in a "fish bowl" may be annoying to the average entrepreneur.

In the case of the private loan, monthly, or at least quarterly, financial reports, extensive in scope, may be required. "In the case of the public offering, semiannual, annual, and interim reports will be required for filing with the Securities and Exchange Commission and for transmission to the underwriter. Informative reports

s See generally Louis Loss \& Edward Cowetr, BluUe Sky Law (1958). 
should be sent to the stockholders at least annually. Good working relationships with the underwriter, the stockholders, and the securities markets are of importance. As the company grows, it may need further financing. Antagonistic underwriters and stockholders are not the best source of additional funds.

Often, after the company has put its best foot forward and obtained the necessary funds, there is a period in which earnings not only do not live up to the initial promise, but drop below the latest period included in the registration statement. In part, this may result from the fact that management has devoted an extraordinary amount of time to the financing, to the detriment of sales and profits. The drop in profits may raise problems concerning continuation of dividends. If the prospectus has included a statement of policy to declare such dividends, their discontinuance will shake the confidence of the stockholders. There is at least a moral obligation, and there may be some legal obligation, of directors to use their best efforts to pay the dividend indicated in the prospectus.

It is of importance that the funds received from external sources be devoted to the stated purposes for which they were raised. The representation in the registration statement (or the representation to the institutional lender) is a matter of importance to which management must adhere. The development of unusual circumstances may at times justify some departure from the initial intention, but that departure must be well based.

After the issue is sold, the underwriter will be responsible for developing a market in the securities. A small issue cannot, of course, be the basis for a broad market, but an active and aggressive syndicate can provide a satisfactory market, even in the case of an issue thought to be small. Generally speaking, over a period of a year or two, the $\$ 1,000,000$ issue should develop $75^{\circ}$ to 1000 stockholders or holders of debt, and sometimes substantially more. With this number, a market with some depth should result.

The small company may wish to consider listing on the American Stock Exchange. ${ }^{65}$ As a general rule, the distribution of 100,000 to 125,000 shares among 500 or more stockholders and earnings in the six-figure area will enable the issuer to obtain a listing on the American Stock Exchange. Whether such listing is wise or justified in each case is a matter for consultation between the company and the underwriter. On the one hand, listing may limit activity in the market; commissions on the Exchange are below the trading profits which may be available to the underwriter in the over-the-counter market. Since salesmen seek the most profitable activities for their time, it may be difficult to interest them in the lower commissions. As a result, the market may be a thin one, and a thin market is sometimes worse than none, since it creates the impression of a market price which is not, in fact, a sound one. On the other hand, the underwriter may prefer to have the issue listed on the Exchange for status and recognition, and enhancement of collateral loan values (depending on current margin regulations). There are other advantages to the in-

\footnotetext{
${ }^{E}$ The requirements of the New York Stock Exchange are beyond most small businesses.
} 
vestor and the issuer in the maintenance of a recognized, orderly market in the stock.

Among the problems that may arise, postfinancing, will be those having to do with expansion by way of merger or acquisition. Once the company has sold its stock to the public, it may find that smaller competitors or suppliers will be interested in joining the organization and merging their businesses so as to achieve the benefit of larger-scale operations. Each such project must be carefully examined and discussed with the underwriter, whose assistance may be required eventually in order to finance the acquisition. Mere size is not, of course, a virtue; a combination of unprofitable businesses does not automatically lead to profits. However, among the benefits of the financing may be the ability of the issuer to expand more quickly by acquisition of businesses not large enough to do their own financing, but important enough to add to the profit and growth potential of the company.

\section{VIII}

\section{Small Business Investment Act}

To supplement prior sources of equity capital and term loans for small business, Congress adopted the Small Business Investment Act of $195^{8}$, which became effective on August 2I, I958. It is the declared purpose of the $\mathrm{Act}^{56}$

to improve and stimulate the national economy in general and the small-business segment thereof in particular by establishing a program to stimulate and supplement the flow of private equity capital and long-term loan funds which small-business concerns need for the sound financing of their business operations and for their growth, expansion, and modernization, and which are not available in adequate supply.

The Administration is now establishing its operation, mechanism, and policies. At this point, it is possible only to sketch the framework of the statute and of the regulations adopted to implement it. $^{57}$

In general, the Act and rules permit the licensing by the Small Business Administration (SBA) of "small business investment companies" to provide funds to "smallbusiness concerns" through the purchase of convertible debentures (which are considered equity securities) and securities evidencing long-term loans. The SBA will examine and supervise the operations of its "licensees," which may borrow funds (under specified conditions and circumstances) from the SBA and private sources. An aggregate of $\$ 250,000,000$ of loans by the SBA to investment companies may be outstanding at one time, but only $\$ 50,000,000$ may be borrowed by the SBA from the Treasury during the first year of operation, and an additional $\$ 100,000,000$ during the second year.

\section{A. "Small-Business Concerns"}

The ultimate borrower or issuer under the Act is the "small-business concern." Such a concern is defined by the original Small Business Act as "one which is in-

\footnotetext{
${ }^{88} 7_{2}$ Stat. 689, 15 U.S.C.A. \$ 661 (Supp. 1959). ${ }^{87} 23$ Fed. Reg. 9383-91 (1958).
} 
dependently owned and operated and which is not dominant in its field of operation." TS The Regulations of the SBA under the new Act provide further :9 $^{59}$

A parent company must be considered together with all of its affliates in determining its eligibility as a small business concern. If a concern is a wholly-owned subsidiary of another concern or is under its control or is under its potential control, it shall be considered an affiliate, and a concern may be an affiliate of another concern if both are owned or controlled by a third party.

A controlled affiliate is not deemed to be independently-owned. This provision of the definition may pose problems in the case of a corporation owned by a person who operates his business on a multicorporation basis, for tax or operating reasons. Only the controlling entity would be eligible for loans.

A concern is not considered small if its stock has a public market or if it has obtained public financing in excess of $\$ 300,000$ within the past three years. A business concern which has no public market for its securities is not considered small if its total assets (including those of its affliates) are more than $\$ 5,000,000$ or if "its total income after taxes, together with all of its affiliates, has averaged over $\$ 150,000$ per annum during the preceding three years as reported to the Internal Revenue Service." Exceptions from these limitations may be made by the SBA on application. $^{60}$

\section{B. Equity Capital and Term Loans}

Under the statute, capital is to be provided "only through the purchase of debenture bonds (of such concern)" which are convertible at the option of the holder into stock at "sound book value" determined at the time of the issuance of the debentures." "Sound book value" is the value per share based on "consideration of all pertinent factors, including the actual value of the assets of said small business concern and the relationship of the earnings of such concern to its invested capital." Interest rate and other terms, including maturity date, may be fixed by the parties, but interest may not exceed the legal limit (or, where no such limit exists, the maximum set forth in the original "proposal" and approved by the SBA). ${ }^{63}$ The debentures are to be callable on any interest payment date at face, plus accrued interest. ${ }^{.4}$ There appears to be no prohibition against convertible debentures subordinated to other securities or claims.

${ }^{68} 72$ STAT. 384 , 15 U.S.C.A. $\$ 632$ (Supp. 1959).

50 107.103-I, 23 FED. REg. 9384 (1958).

'I Ibid. Heretofore, the Administration's standards for determining whether a firm is small have related primarily to size of employment. Under 250 employees, a concern has been prima facie considered a small business concern, and over 1,000 , a large business concern. In between, standards have varied from industry to industry. The Administration has also classified as small, wholesale concerns with total sales of $\$ 5,000,000$ or less, and retail or service trades with sales or receipts of $\$ I, 000,000$ or less.

ox Small Business Investment Act of 1958, $\$ 304$ (b), 72 STAT. 693, I5 U.S.C.A. $\$ 68_{4}$ (Supp. I959).

02 I07.304-I (d), 23 FED. Reg. 9389 (1958).

os $107.304^{-1}(\mathrm{f})$, ibid.

os $107.304-\mathrm{r}(\mathrm{b})$, ibid. 
The investment company may provide that a small business concern shall not incur any further indebtedness without the approval of the investment company, which shall have the first opportunity to finance such additional indebtedness (except short-term credit or open-book loans). The issuer of capital debentures is required to invest from two to five per cent of the proceeds of the issue in stock of the investment company; and such stock may not be repurchased by the investment company so long as it is indebted to the SBA. ${ }^{65}$

In addition to convertible debentures, the small business concern may obtain funds from the investment company by term loans. ${ }^{86}$ Such loans are to have a maturity of not less than five years, nor more than twenty years (with a possible tenyear extension), but loans for terms less than five years may be made when necessary to protect prior investments. The loans are required to be "of such sound value, or so secured, as reasonably to assure repayment." This may be interpreted to preclude subordinated loans. The lender may not, as a condition of such loan, acquire any stock or other proprietary interest in the borrower, except through the medium of collateral security. Hence, this section of the Act may not be used as a substitute for the capital debenture provisions. As in the case of the convertible debentures, interest rate is not fixed, but may not exceed the local statutory limit (or, where there is no such limit, the maximum approved by SBA).

Although the conditions of all term loans and debentures are, in general, subject to SBA approval, the Administration has indicated that it intends to permit the parties to negotiate their own terms, within the framework of the policy and program which form the basis of the original license. Only major variations from such basic terms will require specific SBA approval. ${ }^{\text {.7 }}$

Unless the Administration shall otherwise approve, the aggregate amount of debentures and loans of any small business concern acquired by a small business investment company may not exceed twenty per cent of the combined capital and surplus of the small business investment company. ${ }^{68}$ Transactions may, however, be undertaken in conjunction with other financial institutions, including other investment companies.

\section{Small Business Investment Companies}

Loans and investments are to be made by small business investment companies which are to be organized under the laws of the state (or one of the states) of operation, where possible. In certain cases, a federal charter may be granted, but such charters will probably be issued only rarely. ${ }^{60}$

The regulations of the SBA specify in some detail the provisions of an investment company charter. Each company is to conduct its operations in a specified area (but

os 5 ro7.304-I (g), (h), (i), ibid.

io 305, 72 STAT. 693, 15 U.S.C.A. \$ 685 (Supp. 1959).

of 107.304-I (i), 23 FED. REG. 9389 (1958).

es 5 ro7.306-I(a), id. at 9390 .

19 301 (a), 72 Stat. 69I, 15 U.S.C.A. \$ 68I (Supp. 1959). Chartering under the Small Business Investment Act of 1958 will involve problems of federal incorporation not within the scope of this article. 
there is no limitation on the area from which it may draw business). The investment company will be authorized not only to make loans and purchase convertible debentures, but to provide consulting and advisory services on a fee basis. Business may be generated and loans and investments may be investigated and serviced through, or in cooperation with, banks and other financial institutions. ${ }^{\mathbf{7 0}}$

The Act provides that investment companies may be formed by any number of persons not less than ten, and shall have nine directors. ${ }^{71}$ The Regulations provide, however, that an investment company which receives its charter from a state shall conform to the laws of such state with respect to the number and qualifications of incorporators and directors, whereas an investment company that receives an SBA charter shall adhere to the standards of the Act. ${ }^{22}$

In order to form a small business investment company, the organizers or "proponents" must file a proposal with the SBA, including a description of proposed investment and loan policies, and data regarding charter, bylaws, officers, directors and principal stockholders, and similar matters. The proposal must establish need in the proposed operating territory, and by concerns of the type intended to be assisted by the investment company. The proponents must also include a plan acceptable to the SBA for expansion of the resources of the investment company by sale of securities to investors. ${ }^{73}$ Once the proposal is approved, an application in specified form must be filed, on which the permit is based. ${ }^{74}$ Investment policy, borrowing and capital expansion plans, and officers, directors, and principal stockholders may not be changed without SBA approval..$^{75}$

No investment company may commence business without at least $\$ 300,000$ in capital and surplus. ${ }^{76}$ The Act provides that the SBA may purchase subordinate debentures to the extent of one-half of such initial capital; and that such debenture capital is to be deemed a part of the capital and surplus of the company for specified purposes, including loan ratios. ${ }^{77}$ An investment company licensed to operate by the SBA may borrow up to fifty per cent of its capital and surplus (including such capital debentures) from the SBA. It is intended that government funds shall be available only to the extent that funds are not obtainable from private sources, but unavailability of private funds may be established by certificate of the investment company. ${ }^{78}$ The ratio of outstanding indebtedness to paid-in capital and surplus (including subordinated debentures) may not exceed four to one. ${ }^{79}$

The debentures and other debt securities issued to the SBA by the investment company are to mature in twenty years, bear interest at five per cent, and be amortizable in the second half of the term. ${ }^{80}$ Investment companies will be required

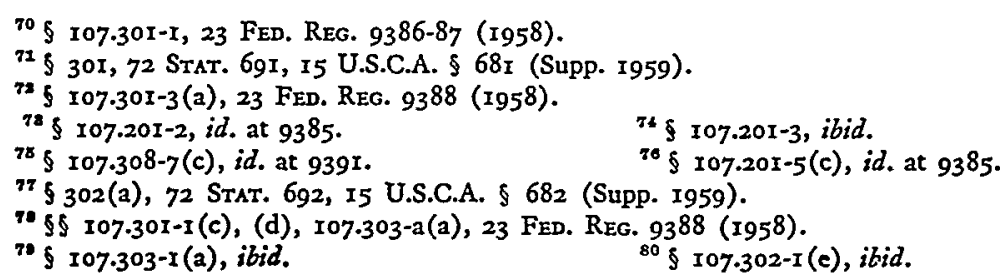


to use SBA term loans as a revolving fund, making repayments when possible and reborrowing when funds are needed. ${ }^{81}$ Without SBA consent, an investment company may not make investments in or loans to small business concerns having a common officer, director, or ten per cent stockholder (nor advance funds to any officer, director, or ten per cent stockholder of the investment company) ${ }^{\mathbf{} 2}$

No government funds may be obtained by an investment company unless its executive and at least three directors certify, among other things, that the capital of the investment company is not impaired. Impairment is declared to exist when deficit exceeds either paid-in surplus or fifty per cent of combined capital and paid-in surplus. This may involve problems of investment valuation of considerable difficulty. The certificate must also state that the funds are to be employed in accordance with the Act within thirty days after receipt. ${ }^{83}$

\section{Development Companies}

The Administration is also authorized to make loans to state and local development companies. Such loans are to be on a secured basis and are to be used for relending or other assistance to identifiable small business concerns and for a sound business purpose approved by the SBA. Loans are limited to $\$ 250,000$ per small business concern. Lending to local development companies is to terminate on June $30,1961 .{ }^{84}$

\section{E. Tax Benefits}

The 1958 tax acts $^{85}$ added three new provisions to the code governing losses on investments in small business concerns and small business investment companies. ${ }^{86}$ An investor in the stock of a small business investment company organized under the Small Business Investment Act can take as an ordinary loss deduction (rather than as a capital loss) all losses resulting from investment in such stock, and the losses are considered as attributable to the trade or business of the taxpayer. Certain technical restrictions surround this provision, but in general, it permits the investor to write off his stock in a small business investment company as a business expense, without limitation as to amount.

The investment companies can take as an ordinary loss deduction (rather than as a capital loss) all losses realized from worthlessness, sale, or exchange of the convertible debentures (including stock received on conversion) purchased under the Act. This provision does not, however, apply to losses incurred as a result of term loans made under section 305 of the Act. The Internal Revenue Code further provides that investment companies may take as a deduction 100 per cent of the dividends received from a taxable domestic corporation, rather than the ordinary

${ }^{82}$ \& $107.303-3$, ibid.

88 ई $107.308-1,-2$, ibid.

${ }^{82} \S$ ro7.303-3, ibid.

$84 \$ \$$ 501.02, 72 STAT. 696-97, 15 U.S.C.A. $\$ 696$ (Supp. 1959).

${ }^{85}$ The Technical Amendments Act and Small Business Revision Act of 1958, 72 Stat. 1676 (codified in scattered sections of 26 U.S.C.).

8s INT. REV. CODE OF 1954, \$\$ T242-44. 
eighty-five per cent credit. An investment company may be classified as a personal holding company under certain circumstances.

Any individual investor in common stock of a small business concern may take as an ordinary loss attributable to his trade or business a loss resulting from such investment. This benefit is allowable only to the original stockholder, and not to a transferee. The maximum allowable to a single investor as an ordinary loss in any one taxable year is $\$ 25,000$; and on a joint return, $\$ 50,000$. A small business concern for this purpose is one which offers common stock (for a period of not more than two years) for money or property, pursuant to a plan adopted after June I958, if, at the time of the adoption of the plan, the sum of the proposed offering (plus other amounts received from stock after July I, I958) does not exceed $\$ 500,000$ and the aggregate capital including the offering does not exceed $\$ 1,000,000$.

\section{F. Securities Regulation}

Securities offered by small business investment companies will be subject to registration under the Securities Act of 1933 and Trust Indenture Act of $1939,{ }^{87}$ except where the respective acts provide exemptions. The principal exemptions from the Securities Act are those relating to issues under $\$ 300,000,{ }^{88}$ intrastate offerings, ${ }^{89}$ and private offerings. ${ }^{90}$

The Securities and Exchange Commission has published a proposal to adopt Regulation E, extending to small business investment companies the $\$ 300,000$ exemption of the Securities Act of r933. The Regulation is similar in form to Regulation $A$ and would apply to public offerings of small business investment companies not exceeding $\$ 300,000 .^{81}$

The exemptions provided by the Securities Act of 1933 would be applicable equally to small business investment companies. The Small Business Investment Act of I958 provides that each issuer of convertible debentures must invest two to five per cent of the proceeds obtained from the investment company in stock of the latter $;^{92}$ but the Securities and Exchange Commission has published a proposed rule ${ }^{98}$ to extend the private offering exemption to such transactions.

Generally, securities and transactions exempt from the Securities Act of r933 are also exempt from the Trust Indenture Act of 1939. In the few instances where the Trust Indenture Act of I939 applies independently, the problem of compliance is not one of major significance. Of more importance are the provisions of the Investment Company Act of $1940,{ }^{94}$ under which the SEC supervises the transac-

${ }^{87} 53$ STAT. II 49 , I5 U.S.C. $\$ 77$ aaa et seq. (1952).

${ }^{88} \S_{3}(\mathrm{~b}), 48$ STAT. $76-77,15$ U.S.C. $\$ 77 \mathrm{c}(\mathrm{b})$ (1952).

${ }^{80} \S_{3}(\mathrm{a})$ (II), 48 STAT. 75-76, as amended, I5 U.S.C. $\$ 77 \mathrm{C}(\mathrm{a})(\mathrm{II})$ (I952).

${ }^{00} \S_{4}(\mathrm{I}), 48$ STAT. 77, I5 U.S.C. $\$ 77 \mathrm{~d}(\mathrm{x})$ (1952).

${ }^{21}$ Securities Act Release No. 4005, Dec. 17, 1958.

$09 \$ 304$ (d), 72 STAt. 693, 15 U.S.C.A. \$ 684 (Supp. 1959).

${ }^{93}$ Rule I5I under the Securities Act (and Rule N-3C-I under the Investment Company Act), Securities Act Release No. 4015, Jan. 13, I959. [After this article had gone to press, both of these Rules were formally adopted. Securities Act Release No. 4033, Feb. 13, r959. Ed.]

54 STAT. 789 (1940), I5 U.S.C. $\$ 80 a-I$ et seq. (I952). 
tions of investment companies. That Act was adopted originally to protect investors in the extensive operations of companies which are primarily public investment media, but it appears to be applicable to small business investment companies, unless a specific exemption is available. ${ }^{95}$

Section 3(c)(I) of the Investment Company Act of 1940 provides that any "issuer whose outstanding securities (other than short-term paper) are beneficially owned by not more than 100 persons and which is not making and does not presently propose to make a public offering of its securities," is not subject to regulation under the Act. ${ }^{98}$ Under the SEC's proposed rule, sales of stock by the investment companies to the small business concerns, required by the Small Business Investment Act, would not constitute such a public offering; and an investment company would not be subject to the Investment Company Act until its stockholders numbered more than roo or until it made a public offering of its securities.

Section 307 of the Small Business Investment Act of $x 95^{8}$ provides that the Securities and Exchange Commission may exempt from the provisions of the Securities Act of 1933, and of the Trust Indenture Act of 1939, any class of securities issued by a small business investment company. ${ }^{97}$ The Commission also has broad exemption authority under the Investment Company Act of 1940.88 No special exemptions have yet been granted or proposed for small business investment companies, except Regulation E and Rule I5I.

The power of the SEC to grant special exemptions applies only to securities of the small business investment company, and not to securities purchased by the investment company from the small business concern. The sale by the small business concern to the investment company of its convertible debentures or term obligations for investment would ordinarily be a private transaction exempt under the provisions of the Securities Act of I933. However, if in the original proposal to the SBA it is stated to be the policy of the investment company to redistribute all securities of small business concerns to the public as soon as practicable, the private offering exemption may not apply.

Resales of the convertible debentures will involve other Securities Act problems. Ordinarily, securities exchanged by a corporation with its existing security holders exclusively are exempt from registration. ${ }^{99}$ However, the Commission has recently interpreted the Act to preclude an exemption where the conversion privilege is exercised for the purpose of making a public offering of the underlying stock. ${ }^{100}$

05 "The bill provides also that, with one exception, the Investment Company Act of r940 shall apply to small-business investment companies just as it does at present to other investment companies." SenATE Report 13. The Small Business Investment Act of 1958, \$ 307, 72 Stat. 694, Is U.S.C.A. \$ 687 (Supp. 1959), exempts investment companies from certain provisions of the Investment Company Act of 1940.

${ }^{08} 54$ STAT. 798, 15 U.S.C. \$ 80a-3(c)(r) (1952).

${ }^{\circ 7} 72$ STAT. 694, 15 U.S.C. 687 (Supp. 1959).

is $\$ 6(c), 54$ STAT. 802, 15 U.S.C. \$ 80a-6(c) (1952).

${ }^{98}$ Securities Act of 1933, $\$ 3(\mathrm{a})(9), 48$ STAT. 75-76, as amended, 15 U.S.C. $\$ 77 \mathrm{C}(\mathrm{a})(9)$ (1952).

${ }^{100} \mathrm{Cf}$. In re Gilligan, Will \& Co., Securities and Exchange Act Release 5689, May 7, 1958, where the Commission stated: "Quite apart from the question whether Gilligan and registrant originally intended to sell the 1955 debentures when they acquired them from Crowell-Collier, it is clear that when they con- 
It may also be concluded that any public distribution of convertible securities involves a public offering of the underlying stock by the issuer. In such event, registration would be required in every case of public sale of debentures or underlying stock, except (absent control problems) where the investment company (or its nonpublic transferees or associates) exercised the conversion privilege and held the underlying stock for investment, making a public distribution of such stock later only under conditions not inconsistent with the original investment intention.

Problems of seeming conflict between state securities and corporation laws and the new Act will arise. It will take some time before such problems can be considered and conflicts resolved. Early conferences with state securities commissioners and other affected agencies may be in order.

\section{G. Appraisal of the Act}

The Small Business Investment Act of 1958 has been greeted with great enthusiasm; by November 1958, thousands of inquiries and some "applications" had been received by the SBA. Part of this interest may be traced to stories in the press which have created the impression that the Act may be a "get-rich-quick" device for use by "smart money" with little risk. ${ }^{101}$

It is too early to arrive at definitive conclusions with respect to the method, scope, and effect of the operations of small business investment companies, but a preliminary examination of the statute and its proposed administration hardly supports the popular impression.

Investment in small business is recognized as one of the most speculative areas of financial endeavor. The statute does not solve or ease the problem of finding and developing profitable investments. The success of the enterprise will depend, to a large extent, on the acumen of its management; and the finding of experienced personnel will pose a major problem.

Further, unless the investment company is of considerable size and efficiency at inception, its income from interest, dividends, and fees, at least in the early years, will probably not exceed substantially the costs of administration. The experience of other venture-capital enterprises would indicate that substantial profits, if realized, will result primarily from capital gains. ${ }^{102}$

The attraction of investment in small enterprises has heretofore been limited and, as a result, a substantial gap has existed in the financial sources available to the

verted those debentures into common stock, they acquired such stock with a view to distribution. On this ground, they could be considered statutory underwriters with respect to such stock. Section 3 (a) (9) of the Securities Act provides an exemption where an issuer exchanges securities with its existing security holders exclusively, but would not provide an exemption with respect to subsequent public distribution by a recipient who is a statutory underwriter."

${ }^{102}$ See, e.g., Business Week, Oct. II, 1958, p. 23; Wall Street Journal, Nov. 13, 1958, p. I.

${ }^{102}$ Mr. Robert Linton, Partner in the Stock Exchange firm of Burnham \& Co., and Mr. C. Wrede Petersmeyer, Partner in the firm of $\mathrm{J}$. H. Whitney \& Co., leading venture-capital firm, both expressed the opinion, based on extensive experience in the venture capital field, before "briefing sessions" of the American Management Association held in New York on Dec. I and 2, 1958, that at least in the early years, the investment companies would do well to "break even" on a day-to-day basis. 
small business manager. If the small business investment company is now to fill that gap (or a part of it), it must be by reason of special advantages not heretofore available. The two most important of such factors are "leverage" and tax savings.

\section{Leverage}

A "leverage" position is achieved by common stock investors when a substantial part of the capital funds needed by the enterprise are supplied by others in the form of fixed return debt or preferred stock investment. In such case, net earnings (and losses) accrue disproportionately to the common stockholders. Under the Small Business Investment Act of 1958 , the SBA may purchase a maximum of $\$ 150,000$ of subordinate capital debentures. It may also lend to an investment company an amount equal to one-half of invested capital (including debentures). Hence, it would be possible to obtain the use of $\$ 300,000$ of government funds for $\$ 150,000$ of private investment. In addition, an investment company is permitted to borrow from all sources an amount not exceding four times its capital. If an investment company with minimum capital funds were able to obtain maximum credit accommodation, initial private investment of $\$ 150,000$ could be pyramided to $\$ 1,500,000$ of total funds, with resultant profit leverage (and risk). That leverage possibility has been stressed by the press, but it is highly doubtful that the result described above can be realized in any instance. The lending practices of the SBA have not yet been established, but there is no reason to believe that the Administration will favor those seeking to profit by only minimum investment. Furthermore, it is not realistic to assume that maximum private loans can be obtained until the enterprise has a record of sound and successful investment. The four-to-one ratio of borrowings to capital is only a ceiling and will be based on specific loans and stocks. Credit sources may move slowly to support the new investment company until its portfolio is seasoned. Public investment is apparently to be encouraged, but even here, leverage possibilities will be limited by the standards of investor protection adopted by the SEC and the standards of fairness which will undoubtedly guide the SBA. Some leverage will be achieved, but it is doubtful that it will approach the exciting possibilities described in the press.

\section{Tax Benefits}

An investor in a small business investment company can write off his full investment as a business loss; and the investment company can also charge off its investment losses as business expenses. These provisions are intended to pass on to the ultimate investor tax credits resulting from unsuccessful small business investments. However, to a limited extent, such benefits can be realized without the investment company. ${ }^{103}$ Furthermore, in any case where the principal or sole profits of the investment company are capital gains resulting from realization of investments, the tax provisions permitting charge-off of losses against ordinary income may give the company little advantage. ${ }^{104}$

${ }^{109}$ Cf. INT. REv. CODE OF I954, § I244.

${ }^{104}$ Cf. id. $\S 1312$. 


\section{Bank Affiliates}

Shares of small business investment companies are eligible for purchase by national banks, and by other banks to the extent permitted by applicable state law. ${ }^{105}$ Banks may invest not more than one per cent of their capital and surplus in such stock, and several national banks have expressed interest in forming investment companies, alone or in collaboration with other local banks.

Bank affiliates may have certain advantages, at least initially, over other investment companies. The affiliation would bring prestige and easier access to capital, somewhat easier access to bank customers for investments and loans, and assistance in credit investigation and loan selection. However, the affiliates would also have problems. The experience and standards of the commercial banker are sufficiently different from those of the investment banker to require some orientation in the new field, or supplementary personnel to manage the investment companies. Further, unless the affliated investment company is to be used as a device merely to make substandard or nonbankable loans at interest higher than bank rates, its success and prospects must be judged by the standards applicable to other investment companies, as discussed above. There is no reason to believe that the operations of the bank affiliates will be substantially more profitable or less speculative than those of nonaffiliated companies.

This type of operation has been thought inappropriate for banks for the past twenty-five years. Whether state banks will be permitted now to operate freely in the field must wait consideration by state banking authorities of the wisdom of such investments; and even in the case of national banks, activities under the new Act will be affected by regulatory policies yet to be established.

\section{H. General}

Indications are that the small business investment company may prove an attractive vehicle for persons faced with income taxes in the highest brackets who wish to speculate for capital gains in the development of small business concerns. Such persons may find it convenient to accumulate in the small business investment companies contributions of funds which separately might be insufficient for the purpose. Public funds may also be found. In determining whether to operate under the new Act rather than without it, the entrepreneurs must, however, balance the advantages of leverage and tax benefits against the disadvantage and cost of regulation by the SBA, SEC, and, possibly, state agencies.

From the viewpoint of the small business concern seeking capital, the small business investment companies may prove welcome additions to the ranks of venture-capital providers. The new companies will inject additional capital into the field and will be more easily found. The local community will be able to turn to a recognized enterprise which may become as well known as a bank, instead of shopping for small amounts on a more haphazard basis, as heretofore. But, the limita-

${ }^{105}$ Small Business Investment Act of $1958, \$ 302(\mathrm{~b}), 72$ STAт. 692, 15 U.S.C.A. $\$ 682$ (Supp. 1959). 
tions of the source must also be borne in mind. Except, perhaps, in a relatively few instances where the special relationship between borrower and lender makes possible inexpensive administration (and high interest return is a feasible objective) or where trade development and not investment is the principal purpose, the investment companies, as venture-capital enterprises, must make investments which can be liquidated at a capital gain long before the maturity of the debentures. Hence, only concerns which can be developed for ultimate public offering will, in general, find a welcome at the investment company office.

In that connection, the SBA definition of a small business concern to include one with assets up to $\$ 5,000,000$ and average annual earnings to $\$ 150,000$ may be important. An examination of prospectuses and offering circulars covering most issues of less than $\$ 3,500,000$ offered publicly during the past three years indicates that over fifty per cent of such public offerings were made by issuers that would qualify as small business concerns under the definition of the SBA. Such concerns, and those approaching that size, would, of course, constitute the most attractive sources of investments for investment companies. Since the investment companies are to be permitted to solicit the bigger "small business" enterprises in competition with established financial sources, they may be less willing to concern themselves with the smaller and less attractive businesses.

There is, in fact, little reason to believe that the small enterprise below prospective public-offering calibre will find significant help under the new Act. Prospective public-offering calibre cannot be equated with size level, in general, but past experience indicates that few operating companies with assets below the $\$ 300,000-\$ 400,000$ level will be found with the necessary potential. Hence, one must conclude, well over ninety-five per cent by number of all concerns falling within the "small business concern" definition will not be able to find a solution to their problems under the Act. Such companies account for more than forty per cent of the total assets held by small concerns within the area covered by the definition of the SBA. ${ }^{100}$

\section{IX}

\section{ConcLusion}

A significant part of the small business community has access to external capital. Businesses deemed "small" by accepted standards are able to borrow from institutional lenders or to make public and private securities offerings, but they must compete for such capital by outbidding their larger and more experienced competitors.

Size alone usually does not preclude external financing by this segment of the small business community, but such businesses often have disadvantages related to their small size. These include financial inexperience, inadequate management, limited market coverage, volatility of earnings, lack of research and product development, and other similar disadvantages. The small company in an attractive field, with good growth potential, a record of several years operation, and good, alert man-

${ }^{100}$ Cf. Federal Reserve Report $167-69$. 
agement, which has achieved an earnings level in the neighborhood of $\$ 100,000$ to $\$ 150,000$ per year, after taxes, can often find private, institutional, or public funds for its capital needs.

Small businesses below the levels discussed in this paper often have no access to external capital. Concerns which own assets amounting in value to less than $\$ 250,000$ constitute ninety-eight per cent of the number of businesses in the country and account for one-eighth of the country's corporate assets. By almost any standards, such businesses are usually too small to raise external capital; and a good part of those with assets in the $\$ 250,000-\$ 1,000,000$ range have the same difficulty.

Congress has recently adopted the Small Business Investment Act to fill the gap in the financial resources available to the small businessman. Small business investment companies operating under that Act may constitute a worthwhile addition to the capital market, but it is doubtful that they will solve the problems which face many concerns now lacking access to external capital. Such investment companies may find that the inexorable laws of financial economics require them to adhere substantially to present investment standards if they are to operate as profitable enterprises. 